OPEN ACCESS

Edited by:

Alexandre Corthay,

Oslo University Hospital, Norway

Reviewed by:

Akiyoshi Takami,

Aichi Medical University, Japan

Andrzej Gorski,

Ludwik Hirszfeld Institute of Immunology and Experimental

Therapy (PAN), Poland

Charles E. McCall,

Wake Forest Baptist Medical Center,

United States

*Correspondence:

Philip A. Efron

Philip.Efron@surgery.ufl.edu

Specialty section:

This article was submitted to

Molecular Innate Immunity,

a section of the journal

Frontiers in Immunology

Received: 09 January 2018

Accepted: 09 March 2018

Published: 04 April 2018

Citation:

Horiguchi H, Loftus TJ, Hawkins RB, Raymond SL, Stortz JA, Hollen MK,

Weiss BP, Miller ES, Bihorac A,

Larson SD, Mohr AM,

Brakenridge SC, Tsujimoto $H$,

Ueno H, Moore FA, Moldawer LL, Efron PA and The Sepsis and Critical IIIness Research Center Investigators

(2018) Innate Immunity in the

Persistent Inflammation,

Immunosuppression, and

Catabolism Syndrome and Its Implications for Therapy.

Front. Immunol. 9:595.

doi: 10.3389/fimmu.2018.00595

\section{Innate Immunity in the Persistent Inflammation, Immunosuppression, and Catabolism Syndrome and Its Implications for Therapy}

\author{
Hiroyuki Horiguchi',2, Tyler J. Loftus ${ }^{1}$, Russell B. Hawkins', Steven L. Raymond', \\ Julie A. Stortz', McKenzie K. Hollen', Brett P. Weiss', Elizabeth S. Miller', Azra Bihorac', \\ Shawn D. Larson', Alicia M. Mohr', Scott C. Brakenridge', Hironori Tsujimoto², \\ Hideki Ueno ${ }^{2}$, Frederick A. Moore', Lyle L. Moldawer', Philip A. Efron ${ }^{1 *}$ and \\ The Sepsis and Critical IIIness Research Center Investigators ${ }^{4}$
}

${ }^{1}$ Department of Surgery, University of Florida College of Medicine, Gainesville, FL, United States, ${ }^{2}$ Department of Surgery, National Defense Medical College, Tokorozawa, Japan, ${ }^{3}$ Department of Medicine, University of Florida College of Medicine, Gainesville, FL, United States, ${ }^{4}$ The Sepsis and Critical IIIness Research Center, University of Florida College of Medicine, Gainesville, FL, United States

Clinical and technological advances promoting early hemorrhage control and physiologic resuscitation as well as early diagnosis and optimal treatment of sepsis have significantly decreased in-hospital mortality for many critically ill patient populations. However, a substantial proportion of severe trauma and sepsis survivors will develop protracted organ dysfunction termed chronic critical illness (CCI), defined as $\geq 14$ days requiring intensive care unit $(\mathrm{ICU})$ resources with ongoing organ dysfunction. A subset of $\mathrm{CCl}$ patients will develop the persistent inflammation, immunosuppression, and catabolism syndrome (PICS), and these individuals are predisposed to a poor quality of life and indolent death. We propose that $\mathrm{CCl}$ and PICS after trauma or sepsis are the result of an inappropriate bone marrow response characterized by the generation of dysfunctional myeloid populations at the expense of lympho- and erythropoiesis. This review describes similarities among CCI/PICS phenotypes in sepsis, cancer, and aging and reviews the role of aberrant myelopoiesis in the pathophysiology of $\mathrm{CCl}$ and PICS. In addition, we characterize pathogen recognition, the interface between innate and adaptive immune systems, and therapeutic approaches including immune modulators, gut microbiota support, and nutritional and exercise therapy. Finally, we discuss the future of diagnostic and prognostic approaches guided by machine and deep-learning models trained and validated on big data to identify patients for whom these approaches will yield the greatest benefits. A deeper understanding of the pathophysiology of $\mathrm{CCl}$ and PICS and continued investigation into novel therapies harbor the potential to improve the current dismal long-term outcomes for critically ill post-injury and post-infection patients.

Keywords: sepsis, chronic critical illness, persistent inflammation/immunosuppression and catabolism syndrome, innate immunity, inflammation 


\section{INTRODUCTION}

The phenotype of the critically ill patient is evolving. While historically a significant number of these patients would have succumbed to early death, recent diagnostic and therapeutic advances allow many of these patients to survive the acute phase of their disease $(1,2)$. In addition, the modern physician can compensate for the organ failure suffered by many intensive care unit (ICU) patients after the acute phase of an insult, resulting in a decreased hospital mortality (1-3). A prime example of this phenomenon exists among severely injured trauma patients who require prolonged utilization of ICU resources. Advances in early hemorrhage control and physiologic resuscitation strategies for critically ill trauma patients have shifted the frequency distribution of post-injury mortality away from early in-hospital death toward late death (4-6). Septic patients have experienced a similar phenomenon. Sepsis is a complex physiologic condition that represents a major public health challenge. Sepsis is the most expensive hospital condition treated in the United States, with costs exceeding \$27 billion annually (REF; https://hcupnet. ahrq.gov/\#setup). Over the past 30 years, attempts to treat the "cytokine storm" of sepsis have universally failed to improve outcomes. In addition, no single biological response modifier has been approved by the FDA for treating sepsis. However, the "Surviving Sepsis Campaign" initiated in 2002 promotes earlier recognition of sepsis and implementation of best practices that, as now recognized, results in lower in-hospital mortality for patients with sepsis (7). Unfortunately, similar to trauma, improved early survival has led to a new patient phenotype described as chronic critical illness (CCI) (8). The definition of CCI includes ICU length of stay (LOS) greater than or equal to 14 days with evidence of persistent organ dysfunction, measured using components of the Sequential Organ Failure Assessment (SOFA) score at 14 days. According to this definition, approximately $40 \%$ of sepsis patients progress to CCI (9). These sepsis survivors are commonly discharged from the hospital to longterm acute care facilities (LTACs) and skilled nursing facilities where they often fail to rehabilitate and succumb to indolent death $(1,8)$. We believe that individuals who experience a morbid post-ICU hospital course are developing a new syndrome, termed the persistent inflammation, immunosuppression, and catabolism syndrome (PICS) (1). Emerging evidence indicates that the pathogenesis of PICS involves chronic low-grade inflammation, suppressed host protective immunity, and loss of lean tissue (10-13). This review focuses on the role of emergency myelopoiesis and innate immunity in trauma and sepsis and the ontogeny of critically ill patients with CCI and PICS.

\section{PATHOGEN RECOGNITION AND THE INNATE IMMUNE RESPONSE}

\section{Pathogen Recognition}

Severe injury or infection leading to CCI and PICS begins with the recognition of alarmins, primarily consisting of microbial products and damaged tissue (14). The innate immune system relies on germ line-encoded pattern-recognition receptors
(PRRs) to sense components of foreign pathogens and damaged cells to mount host-protective responses (15). These PRRs are expressed on a variety of host cells, including cells of myeloid, endothelial, and epithelial lineages. These PRRs detect conserved microbial components called pathogen-associated molecular patterns (PAMPs) as well as host molecules derived from damaged cells, known as damage-associated molecular patterns (DAMPs). Major classes of PRRs include Toll-like receptors (TLRs), C-type lectin receptors (CLRs), nucleotide-binding oligomerization domain (NOD)-like receptors (NLRs), retinoic-acid-inducible gene-I (RIG-I)-like receptors (RLRs), and receptor for advanced glycation end products (RAGE) (15). The sheer number, diversity, and redundancy of these pathogen-recognition receptors emphasize their essential role in host-protective immunity (Figure 1).

Toll-like receptors (TLRs) are the most broadly studied PRRs. To date, 13 different TLRs have been identified in humans and mice, with slight differences in receptor type and function between species. TLR1-TLR9 are functional in both species, but TLR10-13 is not conserved between species. While some TLRs are expressed on the plasma membrane (TLRs 1, 2, 4, 5, and 6) to constantly sample the local environment, others are located within endosomal compartments (TLRs 3, 7, 8, 9, 11, 12, and 13) to sense host danger signals or microbial proteins and nucleic acids (15). TLRs located on the plasma membrane detect external microbial components and circulating damage signals such as lipopolysaccharide (LPS), phospholipids, zymosan, flagellin, peptidoglycan, S100A8/9, and endogenous high-mobility group box (HMGB) nuclear proteins from distressed cells (16-22). TLRs located in cytoplasm, however, detect viral or microbial nucleic acids as well as the mitochondrial nucleic acids associated with cell injury (23). TLRs play a central role in initiating the innate immune response in cooperation with other PRRs through diverse and overlapping signaling pathways (24).

Pathogen recognition also occurs through C-type lectin receptors (CLRs). CLRs are carbohydrate-binding transmembrane proteins expressed by antigen-presenting cells (APCs). CLRs are able to recognize glycolipids and glycoproteins present on numerous pathogens including bacteria, parasites, fungi, and viruses, as well as on host cells (25). Furthermore, the CLR macrophage-inducible C-type lectin receptor (Mincle) can detect the DAMP spliceosome-associated protein 130 (SAP-130) released by necrotic cells (26).

Nucleotide-binding oligomerization domain-like receptors are a family of more than 20 cytoplasmic receptors. NOD1 and NOD2 were the first identified NLRs capable of recognizing bacterial peptidoglycan moieties and triggering inflammation by activating nuclear factor (NF)-kB and mitogen-activated protein kinase pathways. Recent studies have demonstrated that NOD2 is also capable of sensing viral ribonucleic acid (RNA) $(27,28)$. Other receptors, such as the NLR family pyrin domain containing 3 (NLRP3), detect not only bacterial peptidoglycan but also bacterial flagellin, cytosolic microbial and host deoxyribonucleic acid (DNA), as well as DAMPs, such as adenosine triphosphate and uric acid. These pathogen and damage signals lead to the formation of large protein complexes in the cytosol, termed inflammasomes, which subsequently active caspase- 1 . Activated caspase- 1 in the inflammasome converts the pro-inflammatory cytokines (ILC) 


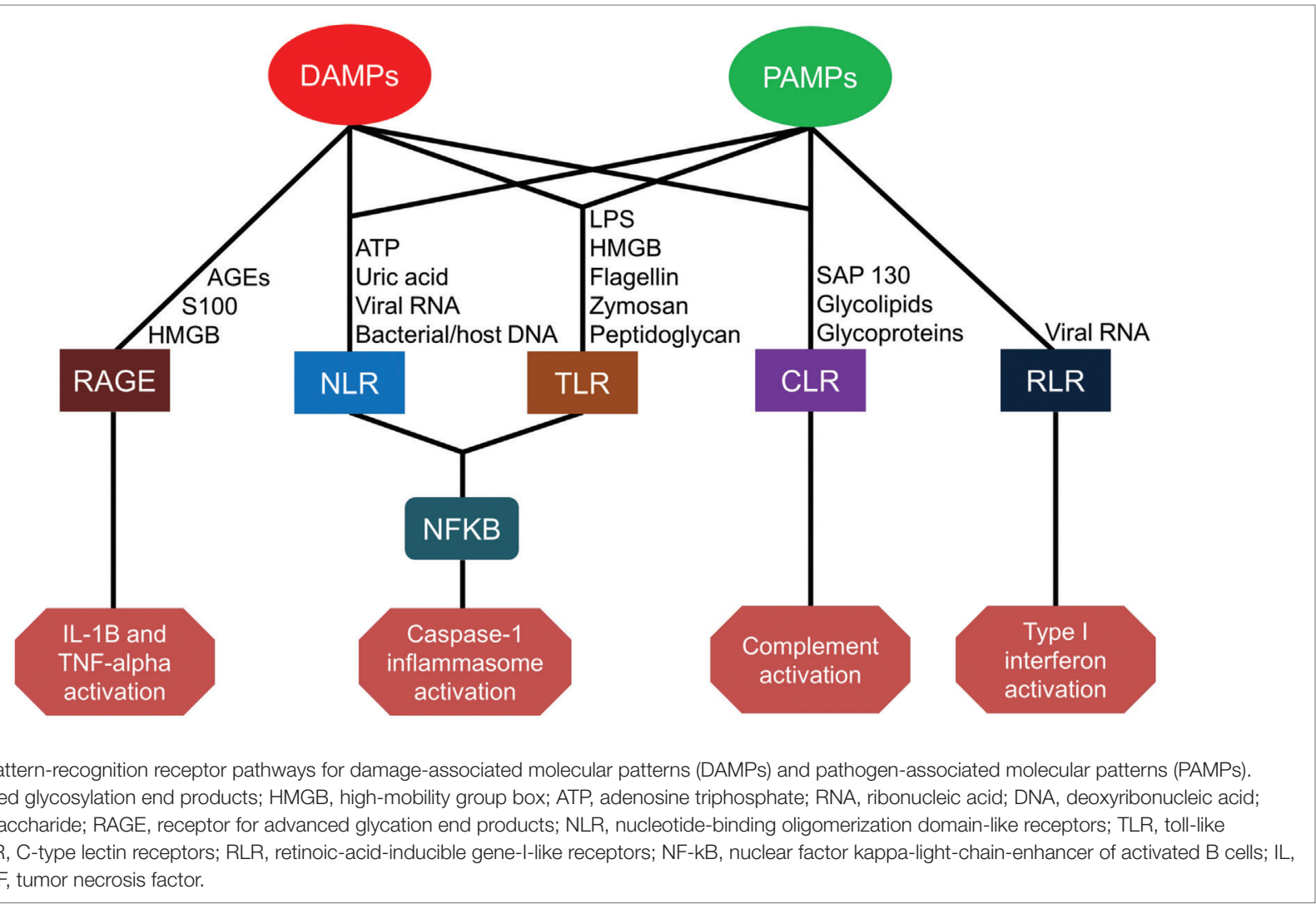

interleukin (IL)-1 $\beta$ and IL-18 into their biologically active forms. In addition, caspase-1 activity induces inflammatory cell death in infected myeloid cells in a process known as pyroptosis (29).

Retinoic acid-inducible gene-I-like receptors are cytoplasmic receptors that comprise RIG-I, melanoma differentiation-associated protein 5 (MDA5), and laboratory of genetics and physiology 2 (LGP2). RIG-I and MDA5 recognize viral double-stranded (ds) RNA and activate the innate immune response (30), whereas LGP2 is reported to play both negative and positive regulatory roles in RIG-I and MDA5 signaling $(31,32)$. RIG-I and MDA5 bind to short dsRNA ( $<1 \mathrm{kbp})$ and longer dsRNA ( $>1 \mathrm{kbp})$, respectively.

Finally, RAGE is a transmembrane receptor expressed on human endothelial cells, monocytes, and lymphocytes. RAGE binds to several ligands including advanced glycation end products (AGEs) from aging erythrocytes as well as HMGB1 and S100 proteins. Interactions between AGEs and RAGE on endothelial cells induce oxidative stress and mitochondrial dysfunction leading to tissue injury (33). HMGB1-RAGE interactions also contribute to cell proliferation, cell migration, and angiogenesis (34). Engagement of S100 protein with RAGE is associated with an increased expression of the pro-ILC IL- $1 \beta$ and tumor necrosis factor-alpha (TNF- $\alpha)(35)$.

\section{Signaling Pathway}

Upon host recognition of PAMPs or DAMPs, PRRs initiate a complex set of downstream signaling events that induce a host-protective response. This includes recruitment and phosphorylation of intracellular intermediates leading in part to the activation of immediate response genes. PRR-signaling pathways are wide ranging and often redundant. For example, the TLR signal transduction employs a Toll/IL-1 receptor domain, which has five adaptor proteins: myeloid differentiation primary response 88 (MyD88), Toll-IL-1 receptor domain containing adaptor protein (TIRAP), Toll-IL-1 receptor domain containing adaptor protein inducing interferon (IFN) $\beta$ (TRIF), TRIF-related adaptor molecule (TRAM), and sterile- $\alpha$ and armadillo motif containing protein (SARM) (36). Most TLRs (TLR-1, TLR-2, and TLR-4-9) utilize the MyD88-dependent pathway, whereas TLR-3 and TLR-4 utilize the TRIF-dependent pathway. The TRIF pathway activated by TLR- 3 or TLR- 4 tends to stimulate the expression of type-I IFNs rather than ILCs. Regardless of the proximal adaptor proteins utilized, TLR signaling terminates in the activation of the transcription factors nuclear factor-kappa $\mathrm{B}(\mathrm{NF}-\mathrm{\kappa} \mathrm{B})$, IFN regulator factor $3 / 7$, and activator protein-1 (AP-1). In addition, TLR signaling induces the secretion of pro-ILCs, type-I IFN, chemokines, and antimicrobial peptides (37). Furthermore, different PRRs may sense the same PAMP. Microbial pathogens are generally composed of several PAMPs, which bind to multiple PRRs simultaneously. Therefore, each PRR can potentiate the recognition of "non-self" antigens to mount an effective immune response against infection.

\section{Innate Immune Response Cellular Response}

Pattern-recognition receptors activation and downstream signaling result in both nonspecific and pathogen-specific host 


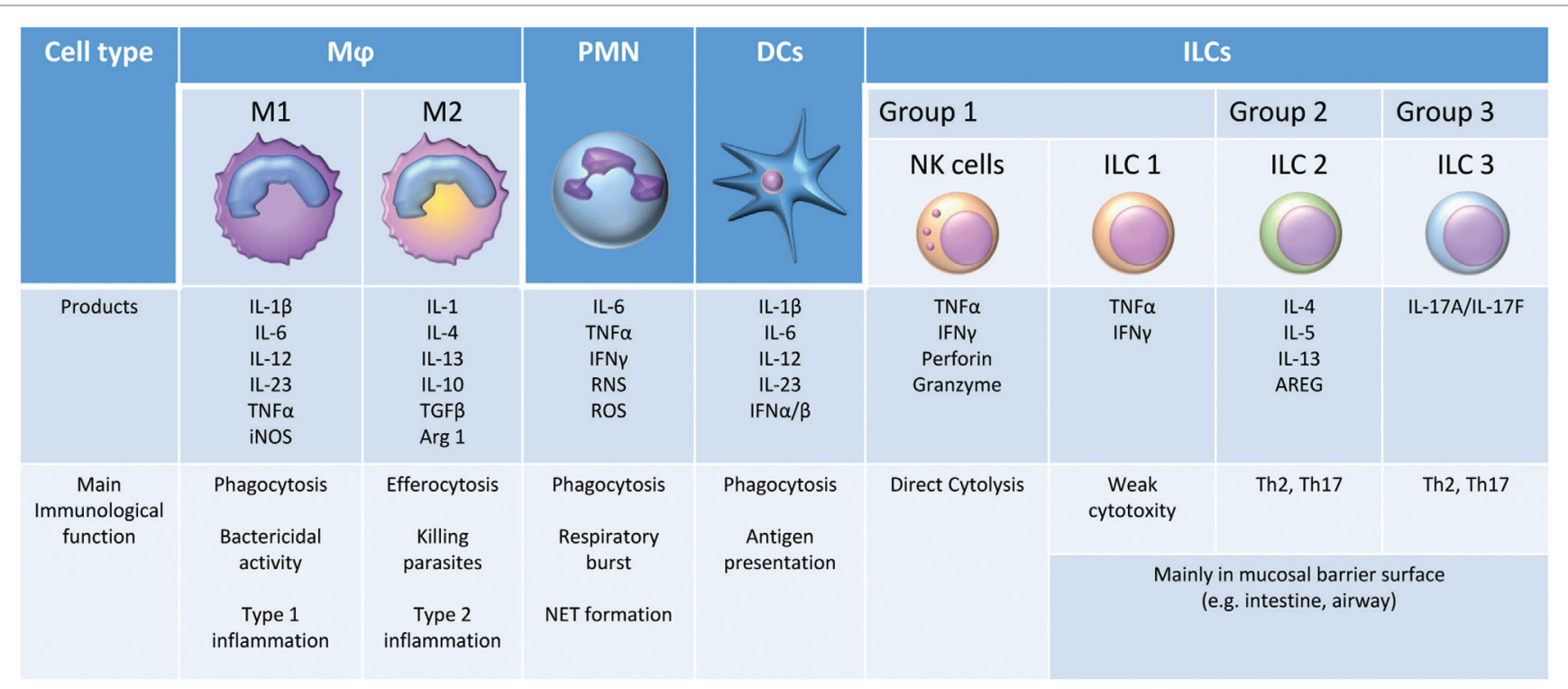

FIGURE 2 | The main immunological functions and products of innate immune cells.

cellular responses to prevent or eliminate host stressors, such as microbial infection or tissue damage (38). The suppression of microbial replication, tissue invasion, and dissemination from the site of infection involves multiple innate immune cells: neutrophils (PMNs), monocytes/macrophages $(\mathrm{M} \varphi)$, dendritic cells (DCs), natural killer (NK) cells, and innate lymphoid cells (ILCs) (Figure 2). All these cells can play a crucial role in the early inflammatory response (39). PMNs primed by cytokines such as TNF- $\alpha$ eliminate invading pathogens through phagocytosis, the production of reactive oxygen species (ROS), and the release of neutrophil extracellular traps (NETs) in a process known as NETosis (40). M $\varphi$ also contribute significantly to the host defense against infection. M1 M $\varphi$, or classically activated $\mathrm{M} \varphi$, are activated by microbial stimuli alone or in combination with other endogenous or exogenous inflammatory signals, such as IFN- $\gamma$ and LPS, respectively, to produce high levels of pro-ILCs (e.g., IL-6, IL-12, and TNF- $\alpha$ ), ROS, and reactive nitrogen species. These early cytokine responses serve two primary purposes: (1) to signal the host regarding the type and magnitude of the infection and (2) to delay microbial expansion and colonization until T- and B-lymphocytes are able to initiate an adaptive immune response, which ultimately contributes to pathogen elimination. DCs are known as professional APCs (41). DCs present pathogen-derived antigenic peptides to $\mathrm{CD}^{+} \mathrm{T}$ cells in lymph nodes, leading to the activation and differentiation of antigen-reactive T-effector cells (42). The NK cell is also an effector cell of innate immunity, producing cytokines such as IFN- $\gamma$ during the early phase of inflammation. In addition, these cells have a direct cytotoxic activity via the induction of apoptosis from the release of perforin, granzymes, TNF- $\alpha$, Fas ligand (FasL), and TNF-related apoptosis-inducing ligand (TRAIL) (43). The crucial role of NK cells in sepsis and trauma is increasingly being recognized (44). Finally, ILCs are another newly described population of innate immune cells. ILC1 cells are weakly cytotoxic but can express several ILCs. ILC2 and ILC 3 cells are thought to promote $\mathrm{T}_{\mathrm{H}} 2$ and $\mathrm{T}_{\mathrm{H}} 17$ responses, respectively, and are critical for the crosstalk between innate and adaptive immunity (45).

\section{Coagulation System}

The innate immune system also incorporates cells and systems beyond effector white blood cells. In a further attempt to control local infections or tissue damage, an endothelial celltarget hypercoagulable state occurs with the presumed intent of reducing blood loss and trapping microbial pathogens (46). This response occurs via multiple pathways (47). Tissue factor (TF), an important trigger of coagulation, is upregulated and decrypted in response to chemical or physical damage, cytokines (such as TNF- $\alpha$ and IL-1 $\beta$ ), and infectious agents (48). TF upregulation leads to the activation of platelets and induction of protease-activated receptor-mediated signaling, resulting in the production of additional cytokines and the expression of cell adhesion molecules. These responses result in the formation of NETs within the vasculature, which bind platelets and promote thrombosis (49). Moreover, platelet activation within the sites of bacterial infection also provides a first line of defense against pathogenic microbial agents (50). Although activated platelets can have bactericidal activity through platelet secretion, platelets contribute more to bactericidal activity by forming plateletbound bacteria bundles, which boost the activity of professional phagocytes such as PMNs and $\mathrm{M} \varphi s$ (51, 52). Furthermore, recent studies suggest that TLRs and the complement system contribute to coagulation and thrombosis $(53,54)$. Plateletderived TLR- 4 has been shown to upregulate TF expression in LPS-induced endotoxemia and microvascular thrombosis in mice (54). Extracellular histones that are released from dying cells contribute to platelet activation and increase coagulation via TLR-2 and TLR-4 signaling (55). 


\section{Complement System}

The complement system is a major component of the innate immune system that has the ability to discriminate self from non-self (or damaged/altered self) and eliminate pathogens that might harm the host. The complement system is a complex network of more than 50 proteins in the plasma and on cell surfaces arranged in a system of proteolytic cascades (56). There are three major complement pathways: the classical pathway, the lectin pathway, and the alternative pathway (57). The classical and lectin pathways are activated with the help of PRRs, whereas the alternative pathway is activated spontaneously without the need for PRRs (58). Regardless of pathway, the complement system culminates in three broad effector pathways: (1) the generation of potent pro-inflammatory anaphylatoxins, (2) opsonization with targeting of pathogen surfaces with complement opsonins, and (3) the direct lysis of targeted pathogens by the formation of membrane-penetrating pores, termed the membrane attack complex (MAC) (57).

Anaphylatoxins (C3a, C4a, and $\mathrm{C} 5 \mathrm{a}$ ) are the activation products of the effector phase of the complement system. Anaphylatoxins are traditionally reported to have diverse pro-inflammatory effects. This includes smooth muscle contraction, an increased leukocyte chemotaxis, vasodilation, an increased vascular permeability, an improved neutrophil oxidative burst, an enhanced phagocytosis, and an increased release of inflammatory mediators like histamine (57). In addition, recent studies have demonstrated that anaphylatoxins are potent mediators of numerous other biological responses, such as the modulation of cytokine expression, increasing the expression of adhesion molecules on neutrophils, the activation of the coagulant pathway, and the regulation of adaptive immune cells (59-64).

Complement-mediated opsonization plays a major role in phagocyte pathogen recognition. Complement component C3 is cleaved into $\mathrm{C} 3 \mathrm{a}$ and $\mathrm{C} 3 \mathrm{~b}$ by enzymes in all three pathways of complement activation. This cascade results in a conformational change of $\mathrm{C} 3 \mathrm{~b}$ that allows the covalent association of $\mathrm{C} 3 \mathrm{~b}$ with the pathogen surface and subsequent cleavage by factor I and its co-factor. Moreover, this conformational rearrangement exposes numerous binding sites for receptors. There are complement C3 receptors including CR1-4 and CRIg that recognize C3b and its fragments. These receptors trigger phagocytosis, promote erythrocyte transportation and clearance, and enhance B cell immunity and regulate T-cell proliferation (65-67).

The MAC is the pore-forming terminal assembly of the complement system (C5b-C9), which leads to cell lysis on the surface of bacteria and other targets. The MAC has diverse roles, including the modulation of cell proliferation and the activation of the inflammatory response. A recent study reported that the MAC on a Rab5 ${ }^{+}$endosome could activate noncanonical pathways for $\mathrm{NF}-\kappa \mathrm{B}$ activation through intracellular signaling and promote the inflammatory response (68).

\section{Bone Marrow (BM) and Myelopoiesis}

Although the early host response is recognized immediately at the site of infection or tissue injury by resident innate cell populations, the recruitment of additional innate immune cells is almost immediate. Large numbers of mature myeloid cells are released from the $\mathrm{BM}$ and are recruited to the site of infection or injury $(69,70)$. Although many chemokines are involved in the recruitment of innate immune cells, one of the most important is C-X-C motif ligand 12 (CXCL12), also known as stromal cell-derived factor 1 (SDF-1) (71). Under normal conditions, high levels of CXCL12 in the BM play a critical role in innate immune cell chemotaxis and retention. However, in response to a host challenge, BM CXCL12 concentrations rapidly decline, and increased levels are seen at the site of infection or inflammation $(72,73)$. This reverse gradient appears to be influenced by the neuroendocrine stress response and may serve as a primary signal for the massive efflux of cells from the BM. In addition, multiple chemokines are required for this integrated recruitment of specific leukocytes at certain times post sepsis or trauma $(69,70)$. In the immediate period, BM niches are created by the exiting cells, and these niches are sensed by mesenchymal cells that reside in the bone and BM. Subsequently, there is a rapid release of proteins, such as FMS-like tyrosine kinase-3 ligand (Flt3L), which drives the proliferation of hematopoietic stem cells (HSCs), primarily of the short-term (ST-HSCs) subtype $(74,75)$. Thus, the numbers of BM lineage-negative, Sca-1 positive, c-kit-positive cells, multipotent progenitor cell (MPP) 1s and MPP2s greatly expand in the acute period following the insult (13).

Interestingly, developing MPPs do not differentiate equally along myeloid, lymphoid, and erythroid populations. Rather, the cytokine milieu present during infection or tissue damage drives myelopoiesis at the expense of both erythropoiesis and lymphopoiesis (76-78). While colony-stimulating factor 1 , IL-3, and granulocyte colony-stimulating factor (G-CSF) concentrations rise dramatically, the compensatory erythropoietin response is blunted and IL-7 production is markedly suppressed. The end result is a preferential differentiation toward myelopoiesis. Consequently, BM is composed of nearly $95 \%$ myeloid cells within several days of sepsis (79). The resulting lymphopenia is exacerbated by T-cell dysfunction and increased lymphocyte apoptosis, and the resulting anemia is exacerbated by hepcidinmediated iron restriction that is minimally responsive to exogenous iron and erythropoietin administration (79-81). These events have a pathophysiologic synergy.

Severe anemia among critically ill patients is often managed with allogeneic red blood cell transfusion. This can lead to transfusion-related immunomodulation and increased susceptibility to nosocomial infection in a population already with dysfunctional innate and adaptive immune systems $(82,83)$. Therefore, the rapid expansion of immature myeloid cells produced in lieu of lymphocyte and erythrocyte progenitors is being studied since its modification could potentially correct several pathologies in the CCI population $(10,11)$.

Many of the myeloid cells in the BM never reach a fully differentiated state. They are released in large numbers as immature myeloid cells. Although they are phenotypically differentiated to granulocyte-like and monocyte-like cells, their cellular function is dissimilar to that of terminally differentiated innate immune effector cells $(84,85)$. The pathophysiology of failure of immature myeloid cells to differentiate into mature granulocytes, monocytes, and DCs is complex, with contributions by the cytokine and endocrine milieu associated with microbial recognition or tissue 
damage. Gabrilovich et al. demonstrated that immature myeloid splenocytes from tumor-bearing animals with active inflammation differentiated into DCs and macrophages after being injected into healthy mice while these injected cells remained immature after being placed into other tumor-bearing mice (86).

The functions of these immature myeloid cells and their role in the sepsis and trauma response are poorly understood (87). Clearly, one fraction of these cells is the myeloid-derived suppressor cell (MDSC) population that has been initially described in the cancer population (88). Currently, two types of MDSCs have been identified, granulocytic and monocytic, both representing their phenotype and their ontology. Regardless, both these cells suppress T-effector cells and weaken the effectiveness of immunotherapies targeting T-cell activation $(89,90)$. The MDSC mechanisms of T-effector and antigen-presentation cell suppression are multifold and differ between the granulocytic and monocytic subtypes. These mechanisms include, but are not limited to, the production of the immune-suppressive cytokines, TGF- $\beta$ and IL-10, the nitrosylation of key proteins on the T-cell receptor, arginine depletion, and the increased expression of T-cell checkpoint inhibitors, including programmed cell death protein ligand 1 (PD-L1), cytotoxic T-lymphocyte associated protein 4 (CTLA4), and B- and T-lymphocyte attenuator (88, 91-93).

MDSCs have a strong phagocytic activity, but are poor antigen presenters, and produce increased amounts of pro-ILCs (e.g., TNF- $\alpha$ and MIP-1 $\alpha /$ CCL3), superoxides, and nitric oxide $(79,94)$. Cuenca et al. demonstrated that the early expansion of MDSC in mice bearing small tumors protected mice from infectious challenges, but massive expansion associated with larger tumor burdens made the animals exquisitely sensitive to both microbial infection and exogenous PAMPs (95).

Among critically ill septic patients, the proportion of circulating MDSCs correlates with the magnitude of the inflammatory response and predicts hospital trajectory and long-term clinical outcomes $(10,11)$. Septic patients with persistent MDSC expansion have a longer ICU LOS, a greater in-hospital mortality, and are more likely to be discharged to a rehabilitation facility compared with patients for whom MDSC populations return to baseline within 2 weeks (10). Therefore, it appears that MDSC persistence, rather than the initial MDSC expansion, may contribute to the pathophysiology of CCI and PICS.

\section{Phagocytosis and Antigen Presentation}

Phagocytosis is a central process in innate immunity that eliminates pathogenic microbial agents and facilitates the presentation of antigens to adaptive immune cells (96). Moreover, this process also contributes to the maintenance of normal cellular homeostasis and wound healing of the host organism (97-99). Phagocytes can be classified into two groups, specifically professional and non-professional phagocytes (100). Professional phagocytes (i.e., neutrophils, monocytes, macrophage, DCs, osteoclasts, and eosinophils) play a major role in pathogen elimination and antigen presentation $(96,101,102)$. Non-professional phagocytes, including epithelial cells and fibroblasts, use this process to help maintain homeostasis $(103,104)$.

To initiate the process of phagocytosis, a direct physical contact between the phagocyte and the target must occur. Residual phagocytes extend membrane protrusions to detect and capture the target (105). Circulating phagocytes then recognize released attractant signals, mostly chemokines, from the site of infection and then migrate to that area (106). Subsequently, various receptors on the phagocytes bind to their ligands on the target and activate the signaling cascade of phagocytosis in the host cell. These receptors are classified as non-opsonic receptors and opsonic receptors. Non-opsonic receptors, such as C-type lectins (Dectin-1, Dectin-2, and Mincle) and scavenger receptor A, can recognize PAMPs as well as ligands on apoptotic cells, whereas opsonic receptors, such as FcR, CR1-4, and CRIg, can recognize the opsonized particles (107). The process of phagocytosis results in the elimination of internalized targets by maturation of the phagosome and fusion of the endosome and lysosome (108). In addition to phagolysosome activity, NADPH-oxidase assembly occurs within the phagosome, and various products such as reactive oxygen intermediates, elastase, and cytokines are synthesized and released into the phagosome where the microbes are killed and the microbial products/antigens are processed (108).

Phagocytes also play an important role in antigen presentation, and as mentioned previously, DCs are especially relevant to this process (41). DC phagosomes engulf the pathogens and perform incomplete proteolysis. The resulting products, which are a suitable size for binding with the major histocompatibility complex molecule (MHC), are presented to lymphoid cells at the plasma membrane (109). Engulfed antigens are then loaded into and associated with MHC II or MHC I molecules and displayed on the cell surface for the activation of lymphoid cells in a process termed cross-presentation (110). In the maturation process, phagocytosis triggers downregulation of their phagocytic capacity (111), and mature DCs migrate to lymph nodes and work primarily as APCs (112). There is a specific loss and alteration in the function of DCs after sepsis, and this contributes to subsequent host immune dysfunction (113-115).

Regarding toxin and pathogen clearance, the liver is one of the most important organs of host defense. In particular, Kupffer cells (KCs) play a major role in immune surveillance, including pathogen identification as well as antigen presentation (116). KCs represent $80-90 \%$ of all tissue macrophages in the entire body and are located in the sinusoid of the liver, adherent to liver sinusoidal endothelial cells (117). KCs phagocytose pathogenic microbial agents through TLRs, complement receptors, and antibody receptors (116). After ingesting pathogenic microbial agents, KCs produce several pro-ILCs and chemokines, which attract NKT cells, neutrophils, and T cells to present microbial antigens, as well as activate these cells for eliminating pathogenic microbial agents (118-120). KCs also phagocytose host cells such as neutrophils and platelets, subsequently producing either proILCs or anti-ILCs to resolve inflammation (117, 121-123).

\section{Apoptosis, Necrosis, and Pyroptosis}

Apoptosis is a non-lytic and usually immunologically silent form of cell death characterized by cell shrinking, chromatin condensation, and membrane blebbing (124). Apoptosis is known to play a major role in physiologic development and tissue homeostasis (125). This process occurs through two mechanisms, known as the extrinsic and intrinsic pathways (126). The extrinsic pathway 
is mediated by death receptors such as TNF receptor 1, Fas, and TNF-related apoptosis-inducing ligand receptors that lead to the subsequent activation of caspase- 8 activation. The intrinsic "mitochondrial" pathway, however, activates caspase-9. Regardless, both pathways culminate in the activation of caspase-3 (127-130). Moreover, apoptosis can also occur through granzymes released by cytotoxic T lymphocytes and NK cells (131). Although apoptotic cell death itself is immunologically silent, apoptotic cells can be engulfed by M $\varphi s$ and DCs which induces the release of anti-ILCs such as IL-10 and TGF- $\beta$ as well as reducing the release of TLR-4 mediated pro-ILCs. Both of these effects can promote the resolution of inflammation $(123,132,133)$. Furthermore, the uptake of apoptotic DCs induces the differentiation of forkhead box P3 (FoxP3)+ regulatory T cells (134). In sepsis, apoptotic cell death is increased in multiple cell types except for PMNs. This includes apoptotic-induced depletion of splenic follicular DCs, B cells, and CD4 ${ }^{+} \mathrm{T}$ cells in septic patients $(80,135-137)$. These anti-inflammatory effects of apoptosis are thought to contribute to early and late poor clinical outcomes after sepsis $(138,139)$.

In contrast to apoptosis, necroptosis is a lytic cell death and thought to result in the release of DAMPs, which leads to immune system activation and extensive inflammation like pyroptosis (140). Necroptosis is initiated by death receptors, such as TNF receptor 1, Fas, and TNF-related apoptosis-inducing ligand receptors, and PRRs including TLR-3, TLR-4, and Z-DNA sensor DAI (141). The downstream activation of these receptors usually results in NF- $\mathrm{KB}$ activation and/or apoptosis. However, the necroptotic pathway can also be induced when caspase- 8 activity is actively inhibited by viral-derived caspase inhibitors. Therefore, the function of necroptosis is thought to be as a backup cell death program that is induced when apoptosis induction fails (142).

Pyroptosis is a lytic form of programmed cell death, which is activated by both the canonical and noncanonical inflammasome. Pyroptosis can be initiated in response to the recognition of PAMPs and DAMPs through PRRs such as NLRs and AIM2 in cytosol. These PRRs form inflammasomes and activate inflammatory caspases that induce pro-ILCs (e.g., IL-1 $\beta$ and IL-18) and pyroptosis. Pyroptosis enhances the inflammatory response through the release of pro-ILCs and improved microbe capture in the phagocyte $(143,144)$. Pyroptosis also contributes to cell death and cessation of other processes such as phagocytosis and antigen presentation. Thus, the balance between the initiation of pyroptosis and the promotion of inflammation while retaining viability is important for host immunity.

Pyroptosis has features that are distinct from necrosis and apoptosis and have important implications for the innate immune response to trauma and sepsis. Apoptosis describes a highly regulated cell death pathway involving multiple caspases in the relative absence of inflammation, whereas necrosis involves the disintegrations of cell membranes with spillage of DAMPs, cell contents, and cell membrane components into the interstitial space, promoting the inflammatory response $(145,146)$. Necrosis may occur in a more regulated fashion termed necroptosis, resulting in a more controlled local inflammatory response (147). By contrast, pyroptosis is a tightly regulated form of cell death that is also associated with a significant inflammatory response (148). Pyroptosis may offer adaptive advantages for patients with sepsis by promoting bacterial clearance via pore-induced intracellular traps (144).

\section{SEPSIS IS CHARACTERIZED BY DYSREGULATION AND OVERACTIVATION OF HOST-PROTECTIVE INNATE IMMUNITY}

Host immune responses to pathogens depend on the magnitude of the physiologic insult. Highly virulent pathogens and host immune impairment may potentiate the host's vulnerability to sepsis. Sepsis is defined as a life-threatening organ dysfunction caused by a dysregulated host response to an infection (149). An overactivated or a dysregulated innate immune response to infection can result in tissue damage, cellular compromise, and molecular dysregulation that lead to organ dysfunction and failure.

\section{Coagulation in Sepsis}

Although the activation of the coagulation cascade is protective in reducing the dissemination of invading pathogens through fibrin deposition $(150,151)$, overactivation of coagulation and subsequent microthrombus formation may lead to disseminated intravascular coagulation (DIC) which can reduce microcirculation and oxygen delivery to tissues (152). This can result in multiple organ failure (153). The prevalence of DIC in severe sepsis has been reported to be as high as $47 \%$ (154). During sepsis-induced activation of coagulation, the function of anticoagulant pathways such as antithrombin, activated protein $\mathrm{C}$, and TF pathway inhibitor (TFPI) can be impaired (155). These impairments lead to increased fibrin formation and insufficient fibrinolysis, which results in microvascular thrombus.

\section{Complement Activation in Sepsis}

The complement system is activated during sepsis, resulting in increased levels of C3a, C4a, and C5a in plasma $(156,157)$. Excessive amounts of these anaphylatoxins can lead to adverse systemic consequences through several mechanisms, including, but not limited to, hemodynamic instability and impaired oxygen delivery (158). In the complement system, C5a is the most powerful inflammatory mediator, and the C5a-C5aR interaction can induce various biological responses. In acute sepsis, C5a plays a central role in the production of both inflammatory and anti-ILCs (159). In addition, the excessive generation of C5a results in the aggravation of the cardiovascular system as well as paralysis of crucial neutrophil functions, such as chemotaxis, respiratory burst, and phagocytosis $(160,161)$. Moreover, C5a regulates the host reaction to sepsis $(61,162,163)$.

\section{Neutrophil Priming and NETs in Sepsis}

PMNs exist in three states: resting, primed and activated. PMNs shift from a resting state in the circulation to an activated state at the site of infection via several priming stimuli, including, but not limited to, cytokines, LPS, and C5a (164-166). During sepsis, excessive priming of PMNs can cause excessive production of ROS, which are released into the nearby environment, resulting in tissue damage (167). Priming of the neutrophil respiratory burst 
is believed to be involved in the pathophysiology of the acute respiratory distress syndrome. In addition, NETs can harm the host during sepsis. Although NET formation can help eradicate a wide range of pathogens in the early phase of the infection, the generation of excessive amounts of NETs, as well as impairment of their degradation by extracellular DNAases within the bloodstream, can damage tissues and endothelia (168). This can induce diffuse thrombosis and lead to DIC and acute organ injury $(169,170)$. Also, extracellular histones released by excessively accumulated NETs are cytotoxic to endothelial and epithelial cells $(171,172)$.

\section{MDSCs in Sepsis}

As mentioned above, MDSCs are a heterogeneous population of immature myeloid cells with the common ability to induce immunosuppression. MDSCs are found in healthy individuals at a low amount in peripheral blood (10), but expand dramatically in cancer, autoimmune diseases, inflammation, and sepsis $(10,79,173-175)$.

Myeloid-derived suppressor cell expansion is thought to be primarily mediated by the Janus kinase protein family leading to the activation of transcription 3 (STAT3). Activation is a second step dependent primarily on NF- $\mathrm{KB}$ activation through the MyD88 pathway. Several inflammatory mediators, such as IL-6, G-CSF, GM-CSF, and VEGF, are involved in the latter pathway (79, 176-179). Moreover, activated MDSCs are upregulated by S100A8/9. Following activation, MDSCs produce multiple mediators such as ROS, inducible nitric oxide synthase, arginase-1, TGF$\beta$, and IL-10 that suppress T-effector and NK cell proliferation and activation, preferentially induce Th2 polarization (180-182). Activated MDSCs from septic mice have been demonstrated to produce several pro-inflammatory factors such as TNF- $\alpha$, RANTES, and MIP-1 $\beta$ in response to LPS administration (79).

Unlike the well-defined role of MDSCs in cancer, the role of MDSCs in sepsis is still controversial. MDSC expansion and immunosuppressive functions are observed in both septic mice and humans $(10,11,79)$. The role of MDSCs in sepsis appears to be time-dependent in septic mice (87). For example, in one study, the adoptive transfer of day 3 MDSCs from septic mice into other septic mice resulted in an increased early mortality, whereas the adoptive transfer of day 12 MDSCs had a protective effect. In other studies, blocking MDSC expansion in septic mice resulted in an increased cytokine production and an increased mortality $(87,183)$.

After sepsis, human MDSC expansion may persist 28 days after the onset of sepsis $(10,11,181,184)$. Acute and chronic expansion of MDSCs after sepsis is associated with an increased incidence of nosocomial infection, adverse in-hospital outcomes, and poor discharge dispositions $(10,11)$. However, the mechanism(s) behind these adverse outcomes associated with an increased MDSC expansion are still poorly understood.

\section{IS THE PREDOMINANT PHENOTYPE OF INNATE IMMUNE ACTIVATION IN TRAUMA AND SEPSIS SURVIVORS}

In previous eras, a substantial proportion of patients who survived severe traumatic injury or septic insults were vulnerable to a non-acute death due to multiple organ failure. In modern ICUs, these patients often do not develop multiple organ failure and instead are subjected to the chronic smoldering organ failure of CCI. As previously discussed, DAMPs and PAMPs bind multiple PRRs, including TLRs, CLRs, NLRs, RLRs, and RAGE, with multiple redundant and converging pathways promoting a robust inflammatory response and emergency myelopoiesis, including the expansion and persistence of MDSCs $(14,185)$. In CCI, the persistent release of these endogenous alarmins perpetuates this inflammatory response and emergency myelopoiesis. Downstream of these pathways, septic patients who develop CCI have persistently elevated plasma SPD-L1, absolute lymphocyte counts, and monocytic HLA-DR expression compared with patients who exhibit rapid recovery (9). Chronic critical illness is associated with an increased incidence of nosocomial infections in both trauma and sepsis patients who develop CCI $(9,186)$. Efforts to better understand the pathophysiology of CCI among critically ill surgical patients are underway (187).

\section{PICS IS THE FINAL COMMON DENOMINATOR OF FAILED RESOLUTION OF THE INNATE IMMUNE RESPONSE}

Post-sepsis and severe injury patients, particularly CCI patients, often fail to achieve immune homeostasis. Rather than resolving the acute inflammation that accompanies these huge insults, these patients develop chronic low-grade inflammation. In addition to ongoing inflammation, these patients experience immune suppression and lean muscle wasting of prolonged duration. Collectively, this constellation of features has been coined PICS, or the persistent inflammation immunosuppression and catabolism syndrome $(1,8)$. Although this syndrome has only recently been defined, this phenomenon has been in existence for many years and is not limited to sepsis patients. Rather, PICS is thought to result from a wide array of pathological processes, including severe traumatic injury, extensive burns, and acute pancreatitis $(1,8,188,189)$.

A similar term that has been described is a series of conditions seen in survivors of ICU hospitalization, "post-intensive care syndrome" (190). "Post-intensive care syndrome" describes new or worsening impairments in physical, cognitive, or mental health status arising after critical illness and persisting beyond acute care hospitalization regardless of its etiology. Unlike the post-intensive care syndrome, the PICS has been proposed as $a$ mechanistic explanation for the poor clinical outcomes observed in CCI patients by describing the immune dyscrasia that follows an inciting inflammatory response $(1,8,190)$. PICS patients may well be the same "post-intensive care syndrome" patients, but the former describes an underlying hypothesis that is being tested experimentally, whereas the latter is a purely descriptive term. These PICS patients, irrespective of the term, are frequently discharged to LTACs and skilled nursing facilities where they often fail to rehabilitate, experience progressive declines in cognitive and functional status, require repetitive rehospitalization, and often result in indolent death $(1,8)$. Interestingly, a recent retrospective study, which investigated the clinical characteristics and long-term quality of life (QOL) after acute pancreatitis patients, determined that these patients can also enter the PICS. These 
patients had significantly lower scores in the QOL assessment questionnaire and a lower rate of returning to work as compared to those of "non-PICS" patients (189).

Recent work shows that patients who develop CCI after sepsis (i.e., patients with ICU LOSs of $\geq 14$ days and ongoing organ dysfunction) exhibit persistent elevations in markers of inflammation out to 28 days after sepsis onset, including IL-6 and IL-8 (8). These patients also have elevated anti-inflammatory markers, such as IL-10, that persist out to 1 month. Along with elevations in pro-ILCs and anti-ILCs, CCI patients demonstrate reduced absolute lymphocyte counts, decreased HLA-DR expression on $\mathrm{CD}_{14}{ }^{+}$monocytes, and elevated plasma concentrations of sPD-L1, all of which suggest impaired host immunity $(9,186)$. Clinically, this immune suppression manifests as an increased incidence of secondary infections and a 6-month mortality in the CCI group compared with rapid recovery patients. Finally, to support a decreased anabolic activity and an increased catabolism, CCI patients demonstrate decreased levels of albumin and insulin-like growth factor-binding protein 3, as well as elevated urinary 3-methylhistidine to creatinine ratios.

Although these cytokines and protein biomarkers serve as signatures for PICS, the detailed mechanisms leading to this persistent inflammation, immune suppression, and catabolism have yet to be elucidated. The discovery of the underlying mechanisms will undoubtedly require further studies, including additional genomic and proteomic analyses, as well as the creation of murine models of PICS, which are currently underway (191-193). Future success in the treatment of CCI will likely require addressing the underlying pathophysiology of PICS, potentially through the use of immunomodulatory therapies. Whether these attempted therapies will impact clinical outcomes is yet to be determined. Ongoing clinical trials testing therapies such as PD-L1 inhibitors in severe sepsis patients may provide further direction. Ideally, these therapies will directly impact dysregulated host immunity and prevent the perpetual cycle of PICS.

\section{Age Modulates Innate Immunity and the Host Response to Microbial Infections}

The number of aged individuals around the world is dramatically rising $(194,195)$. Since the elderly population is expanding, research regarding this population has become increasingly relevant, especially with the escalating economic and healthcare burdens in our society. Older patients are more likely to become critically ill and more likely to develop CCI. The causes of this phenomenon include senescence (normal aging), inflammaging (chronic subclinical systemic inflammation), comorbid conditions, lack of physiological reserve, and disability as well as environmental and epigenetic factors. These elements prevent older individuals from returning to a homeostatic state (194-197). In addition, one-third of all aged individuals suffer from frailty, a dynamic and comprehensive measure of physiologic age rather than simple chronological age $(194,195)$. All of these factors contribute to pathophysiology in the host's organ systems, increasing the risk of disease, disability, and death in older patients, particularly within the first year after the onset of critical illness $(194,195)$.
Severe infection and severe injury illustrate the contribution of aging to poor outcomes. For example, sepsis is primarily a disease of the elderly. While the frequency of hospitalizations with sepsis for patients aged 18-49 years has barely changed from 2000 to 2007 , the frequency of hospitalization with sepsis for patients aged 50-64 years has increased and has risen dramatically for patients aged 65 years or greater (198). Overall, in-hospital sepsis mortality is decreasing, but remains significantly higher in the elderly, and this cohort is more likely to be discharged to skilled nursing and rehabilitation facilities rather than home $(1,198,199)$. A similar phenomenon is observed in the realm of geriatric trauma $(200,201)$. Although trauma is primarily a disease of the young, the volume of geriatric trauma is increasing (202). Advanced age in trauma is associated with a more severe organ failure, infectious complications, increased ventilator days, a longer ICU LOS, an increased 28-day mortality, and an increased likelihood of discharge to skilled nursing or long-term care facilities (203).

When regarding the poor outcomes of elderly patients after critical illness, one must consider the prevalence of chronic disease in the elderly and how modern medicine allows individuals with severe chronic diseases to survive into old age $(1,198,204)$. In addition, age-related alterations in the immune system play a profound role in these poor outcomes. Immunosenescence is a state of age-associated changes in the immune system. Compared to the young, the aged immune system is less able to mount an effective response after challenges with infectious pathogens $(205,206)$. The competency of the adaptive immune system decreases with age, as evident by decreases in naïve peripheral $\mathrm{T}$ cells, repertoire diversity, and immunocompetent $\mathrm{B}$ cells $(205,207)$. Although aged host HSCs preferentially induce myelopoiesis, the effector cells engendered (i.e., PMNs, monocytes/M $\varphi$, DCs, and NK cells) are dysfunctional compared with leukocytes from young individuals (206) (Figure 3).

Inflammaging, defined as a low-grade chronic systemic inflammation established during physiological aging, contributes to all the above conditions seen in the elderly (208). However, one should avoid the misconception that the term inflammaging describes how acute and subacute immune and inflammation responses of aged mammals are merely exacerbations of what is demonstrated in the young. Rather, the aged responses to sepsis and trauma are dissimilar to that of juveniles - a "hyper-cytokine storm" is either markedly attenuated or is not the direct cause of increased morbidity and mortality in the elderly after severe infection or injury $(12,13,203)$. From progenitor to downstream effector cells, the aged response to severe infection or injury deviates from the response observed in younger counterparts.

In murine models, both trauma and sepsis induce a rapid release of mature and immature myeloid cell populations from the $\mathrm{BM}$ in response to endogenous and exogenous danger signals $(87,209)$. This evacuation of cells creates niches in the BM that stimulate emergency myelopoiesis, an endogenous effort to restore adequate numbers of myeloid populations (75). Myelopoiesis is driven at the expense of lymphopoiesis and erythropoiesis $(75,79)$. Interestingly, elderly HSCs have this phenotype and function prior to critical illness. Aged HSCs (specifically LT-HSCs) have myeloid-skewed cell production and a decreased 


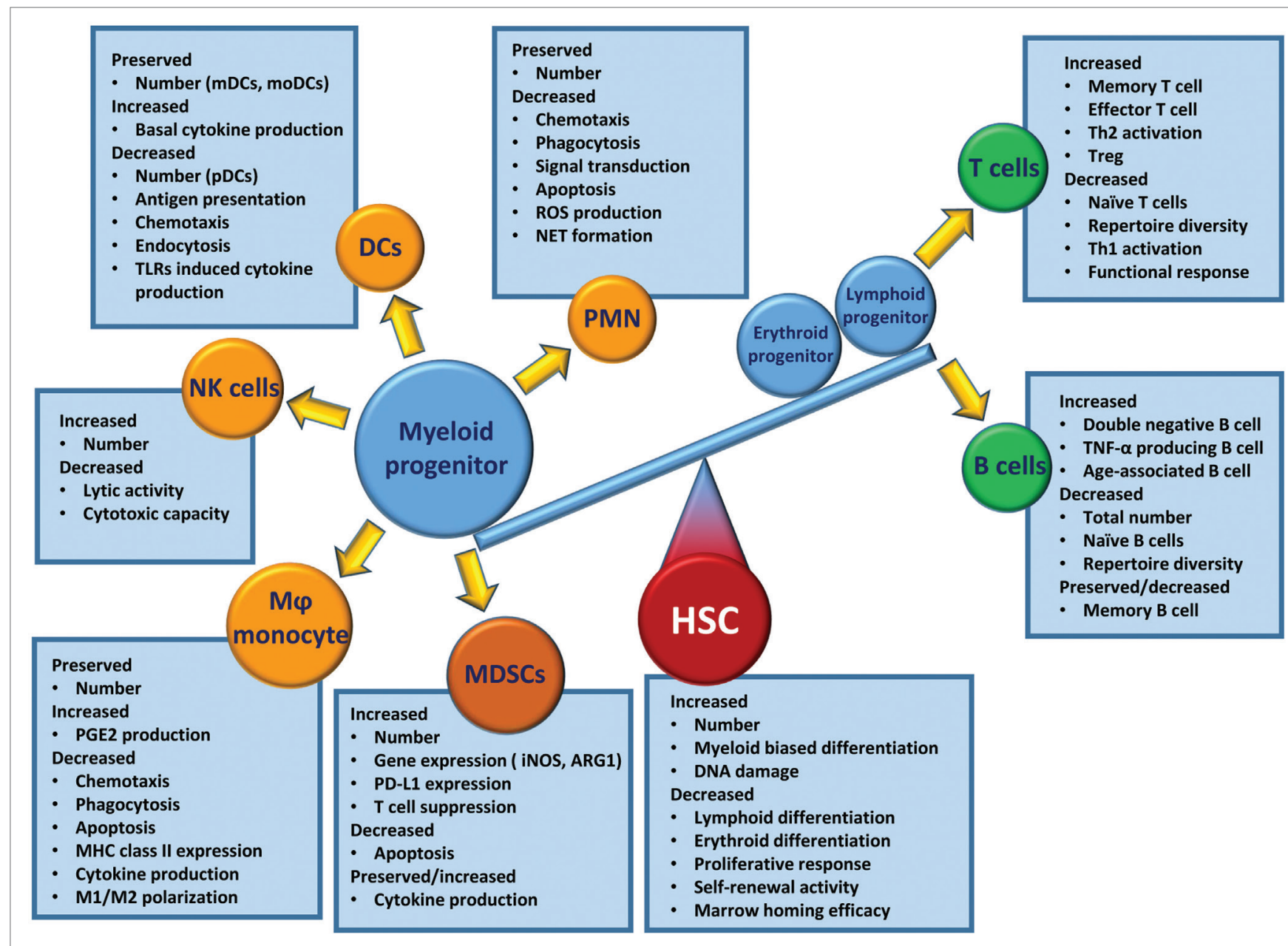

FIGURE 3 | Immunosenescence in hematopoietic stem cells (HSCs), innate, and adaptive immune cells.

ability to produce lymphoid cells $(210,211)$. The number of BM HSCs increases with age, and these HSCs are functionally inferior to their younger counterparts. They have a lower functional frequency, a delayed proliferative response, and a reduced efficiency for short-term BM homing, and they produce smaller clones of mature cells and have a reduced long-term selfrenewal activity $(210,211)$. These HSC dysfunctions are further exacerbated by acute inflammatory insults, such as trauma and sepsis, which induce emergency myelopoiesis $(12,13)$. While the young are capable of returning to a balanced state of innate and adaptive immunity, elderly patients have difficulty returning to homeostasis (203). This results in the elderly having continued specific defects in their effector immune cells.

\section{Like Aging, Cancer Patients Are More Susceptible to PICS}

Many analogies can be made among cancer, aging, and PICS patients. This includes the host innate immune system in each of these conditions. If one asks, "what induces a state of persistent inflammation, immunosuppression and catabolism, as well as being associated with frailty and poor outcomes?" the answer could be cancer, aging, or critical illness. Thus, it is not surprising that all three are related. Both the elderly and cancer patients are more likely to become septic and develop critical illness with poor outcomes $(194,195,212)$. In addition, the elderly are more likely to develop cancer for the same reasons that they are less able to tolerate injury or infection $(213,214)$. Finally, any patient with CCI may develop a systemic phenotype that is similar to that of aged individual or cancer patient, which in its extreme form is classified as PICS $(1,8,185)$.

It is not surprising that cancer patients have an immune environment similar to that of the aged and the CCI population and that this immune status is thought to engender poor outcomes. Cancer patients have persistent antigen exposure and protracted inflammation which eventually lead to pathological effects on host-protective immunity as well as tissue wasting and cellular apoptosis (185). Cancer cells can recruit immune cells to their local environment through the release of local and systemic immunosuppressive mediators (185). Neoplasia can induce immunosuppression through multiple other mechanisms and effector cells, including myeloid-derived suppressor cells, M2 macrophages, T-cell exhaustion, $\mathrm{T}$ regulatory cells, and 


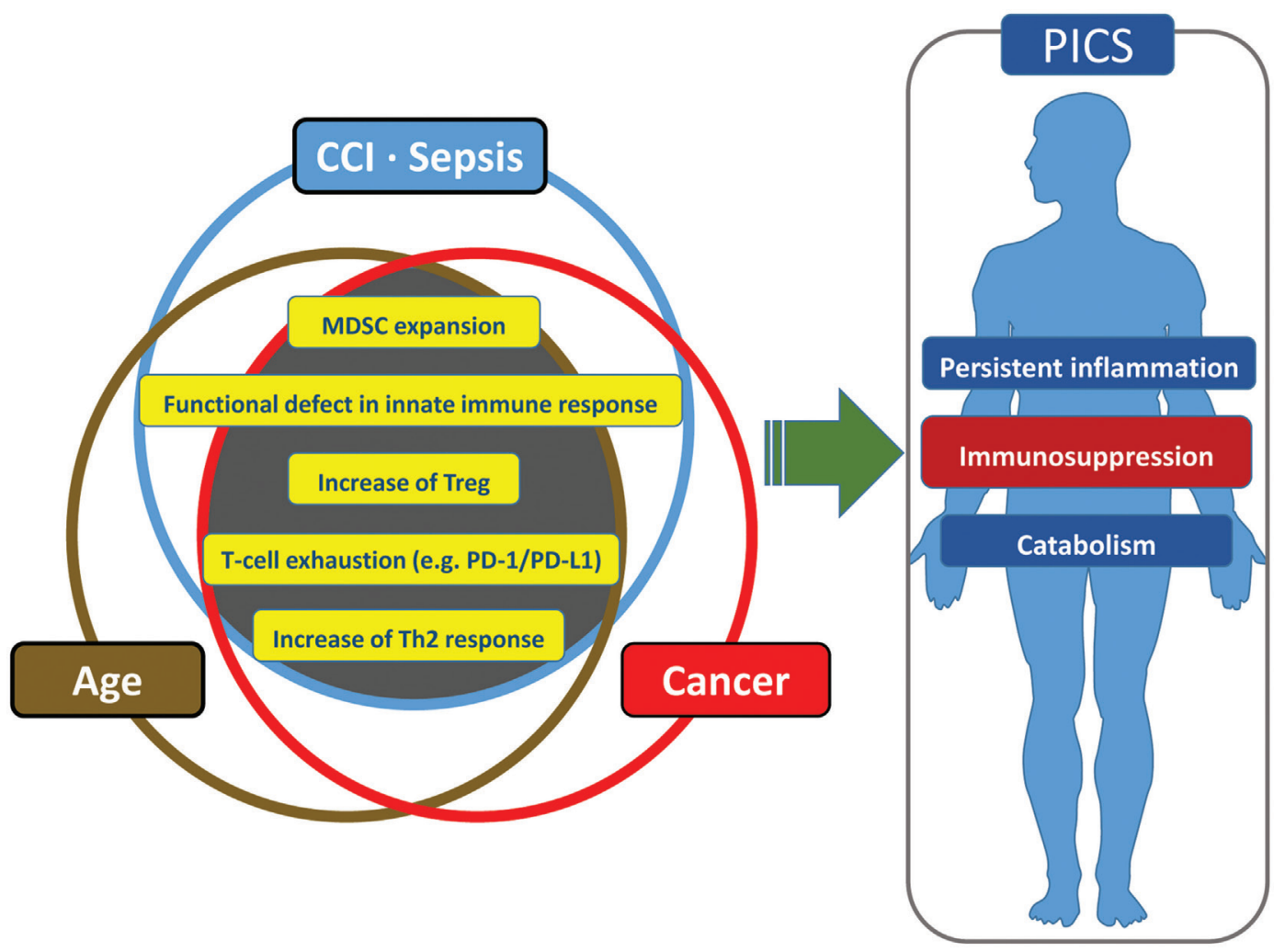

FIGURE 4 | Similarities and redundancies in the pathophysiology of patients with sepsis, cancer, and advanced age.

expression of inhibitory ligands (185). Some have gone so far as to say cancer cells "hijack [host immune] tolerance [and suppression] (215)." It is for these reasons that many researchers are attempting to use approved cancer immunomodulation agents for sepsis therapy (e.g., anti-PD-1/PD-L1 Ab, anti-CTLA-4 Ab) (185) (Figure 4).

Regulation of the hematopoietic response to stress is an integral part of innate immunity (215). Most HSCs are somewhat quiescent, participating in the maintenance of homeostasis (216). However, after injury to the host (e.g., cancer, infection, trauma, burn), HSCs become active, reenter the cell cycle, and undergo differentiation (215). This activation can occur indirectly through mesenchymal or immune cells, or directly through exogenous or endogenous ligands $(217,218)$. Chronic exposure to factors that induce stem cell activity induces HSC defects, including their ability to repopulate (219). One result of this HSC environment is the creation of MDSCs (215). MDSCs represent a wide range of cells in various stages of differentiation and are generated in particular when myelopoiesis is amplified over lymphopoiesis and erythropoiesis (215). The role of MDSCs is still unclear, as their immunosuppressive properties are vital for the resolution of acute inflammation, but they also may play a pivotal role in emergency myelopoiesis in conditions like injury or infection $(87,215)$. Regardless of this paradox, their chronic persistence is associated with poor outcomes in both cancer and sepsis patients $(8,10,215)$.

\section{FUTURE FOR PRECISION MEDICINE AND THERAPEUTICS}

\section{Immune-Modulatory Therapies in Sepsis}

Sepsis is associated with alterations in immune effector cells including defects in antigen presentation, quantitative and qualitative alternation in neutrophils, defective NK cell-mediated immunity, defective $\mathrm{T}$ and $\mathrm{B}$ cell-mediated immunity, relative increases in regulatory $\mathrm{T}$ cells (Tregs), an increased expression of PD-1/PD-L1, decreased immunoglobulin levels, hypercytokinemia, and complement consumption. Immune-modulatory therapies for sepsis are now being investigated, with a focus on the restoration of immune system homeostasis. Agents under consideration include leukocyte growth factors (e.g., granulocyte macrophage colonystimulating factor and G-CSF) (220-224), immunomodulatory cytokines (e.g., IL-7, IL-15, and IFN- $\gamma$ ) (225-229), inhibitors of negative co-stimulatory pathways (e.g., anti-PD-1/PD-L1 Ab, antiCTLA-4 Ab, anti-TIM3 Ab, and anti-LAG-3 Ab) (230-236), and the thymic peptide thymosin- $\alpha 1$ (237). Although some of these agents have previously failed as "silver bullet" curative monotherapies, many have been associated with partial improvements. For example, two randomized clinical trials involving recombinant G-CSF, which is intended to increase neutrophil production and microbial eradication, demonstrated an increase in total leukocyte counts in patients receiving the experimental therapy $(220,221)$. Since emerging evidence suggests that the phenotype of CCI/ 
PICS patients is somewhat similar to that of cancer patients, it is possible that emerging oncologic therapeutic targets and strategies could be successful in treating CCI/PICS.

\section{Nutritional Support and Exercise}

The loss of lean body mass is one of the clinical characteristics of CCI patients. A prolonged low-grade inflammation in muscle may lead to catabolism and myonecrosis that result in the loss of lean body mass $(238,239)$. Thus, nutritional support and exercise are pivotal components in the care of CCI patients. Among CCI patients, optimal amounts of protein intake may be more important than the total daily caloric intake in promoting recovery. However, optimal daily protein administration thresholds for CCI patients have not been elucidated. If CCI patients have similar metabolic requirements as patients with cancer cachexia and aging sarcopenia, then the recommended daily protein intake would be $1.5-2.0 \mathrm{~g} / \mathrm{kg} /$ day $(240-244)$.

Candidate therapies for nutritional therapy in CCI include arginine, leucine, and anabolic adjuncts. The use of arginine in sepsis is controversial because arginine serves as an intracellular substrate for nitric oxide, which may cause pathologic vasodilation. However, the upregulation of arginase-1 in MDSCs has been observed following trauma and sepsis (10, 180), which may result in loss of arginine. Arginine is necessary for T-cell receptor function, as well as ornithine, which is converted to polyamines and prolines that are necessary for wound healing and tissue repair (245-247). Therefore, with MDSC expansion and persistence during PICS, arginine may have the capacity to restore lymphocyte proliferation and promote wound healing and tissue repair. Leucine is one of several branched-chain amino acids (BCAAs), which decreases muscle protein catabolism and induces protein synthesis (248). In a prospective randomized trial, the use of BCAA-fortified parenteral nutrition in surgical patients improved several nutritional and immunological parameters such as nitrogen balance, prealbumin levels, and lymphocyte counts (249). Moreover, recent studies demonstrated that leucine supplementation improves muscle protein synthesis in the elderly and in cancer patients by stimulating the mammalian target of rapamycin (mTOR) pathway $(250,251)$. Thus, leucine or BCAA supplementation may be beneficial in PICS. In addition, several adjuncts such as insulin, oxandrolone, and propranolol have been shown to maintain the anabolic state in patients with burns. These therapies may also be effective in mitigating the catabolic component of PICS (252-254).

Finally, there has been an increasing interest in the functional status and health-related QOL in CCI patients. Early ICU-based exercise and rehabilitation programs have been associated with a reduction in the duration of mechanical ventilation and ICU LOS, as well as improved physical function (255). Studies in non-ICU populations have demonstrated that the combination of exercise and nutritional support has the largest treatment effect on protein synthesis and physical strength compared with nutrition or exercise alone (256). Although the effect of this combination therapy in CCI patients is unknown, the pathophysiology of CCI and PICS suggests that similar exercise and nutritional programs may be useful in these populations as well.

\section{Microbiome}

Since the 1980s, it has been hypothesized that dysregulated crosstalk among the epithelium, immune system, and gut microbiota leads to the development of sepsis and multiple organ failure. In the last decade, a number of studies have produced valuable insights into the pathophysiologic mechanisms responsible for these phenomena (257). Interactions among intestinal epithelial cells and microbiota through signaling of PRRs such as TLRs and NLRs and microbiota-derived short-chain fatty acids (SCFAs) appear to influence both local and systemic immunity. The microbiota influences the development, maturation, and function of myeloid cells in multiple organs and tissues including lungs, intestines, BM, and circulating myeloid cells. For example, germ-free mice demonstrate the reduced development of myeloid cell progenitors in BM (258), and continuous TLR stimulation by commensal microbiota drives neutrophil development (259).

In sepsis, several changes occur in gut physiology and immunity, including loss of gut motility, increased bowel wall permeability, and apoptosis of intestinal epithelium due to extrinsic factors (e.g., antibiotics, opiates, and parental and enteral nutrition) and intrinsic factors (e.g., inflammation and increased bowel wall permeability). These changes may result in the alternation of the microbiota composition $(260,261)$, overgrowth of pathogenic microbes (262), and loss of commensal organisms (263). In patients with the systemic inflammatory response syndrome, there is a loss of diversity in gut microbiota, which is associated with an increased incidence of bacteremia and an increased mortality (260).

However, high-level evidence and recommendations regarding therapeutic modulation of gut microbiota for septic patients are lacking. Several candidate therapies are under investigation, including pro/pre/synbiotics (263), L-glutamine (264), fecal microbiota transplantation (265), and phosphate (Pi) (266). Currently, there is limited evidence to support the use of these therapies for patients with sepsis, and further investigation is warranted.

\section{The Use of Big Data}

The use of big data in medicine has been rapidly evolving. This approach has the potential to provide researchers and clinicians with the information necessary to practice precision medicine tailored to individual patients. For this purpose, there are many databases such as The Human Genome Project (available from: www.genome.gov), Encyclopedia of DNA Elements ( a project to identify all functional elements in the human genome sequence; available from: www.encodeproject.org), Roadmap Epigenetics Project (available from: www.roadmapepigenomics.org), as well as the "Inflammation and Host Response to Injury" Glue Grant (available from: www.gluegrant.org). Big data has already yielded important advances in the field of medicine. For example, tumor transcriptomics are being used to predict pharmacologic and therapeutic responsiveness for some forms of leukemia and solid tumors.

Big data is particularly useful in the translational research approach to sepsis due to the heterogeneity of sepsis populations, the limited utility of individual biomarkers, and the wide variability in the duration and severity of illness prior to 
presentation. For the same reasons, genomic, metabolomic, and transcriptomic markers may be of great value in generating prognostic models and identifying optimal candidates for tailored therapies (267-269). Recently, it has been reported that the leukocyte transcriptome in trauma patients may predict outcomes using samples obtained within 48 h of injury (270). This study and similar studies using regression-based prediction models may be further improved by the use of machinelearning algorithms and deep-learning technologies (271, 272). Although big data provides sample sizes large enough to identify biomarker cutoff values with optimal sensitivity and specificity for the outcome of interest, these static variable thresholds based on aggregate patient populations fail to account for individual patient physiology. Therefore, future efforts should continue to evolve precision medicine approaches for septic patients by integrating data from multicenter and multinational repositories with machine-learning and deep-learning technologies that recognize and manage complex, chaotic, and nonlinear associations among input variables.

\section{CONCLUSION}

Following remarkable advances in our understanding of the pathophysiology and natural history of trauma and sepsis, two major targets for improving outcomes remain: early death and indolent death attributable to CCI and PICS. A better understanding of the pathophysiologic mechanisms responsible for CCI and PICS may allow for the identification of novel management strategies and therapeutic targets. Future research should continue to investigate anti-inflammatory agents, immune modulators, gut microbiota support, as well as nutritional and exercise therapy. These should all be guided by validated prognostic models, hopefully taking advantage of novel "big data" datasets, to identify patients for whom these approaches will yield the greatest benefits. Retrospective "community" big data can also be used

\section{REFERENCES}

1. Gentile LF, Cuenca AG, Efron PA, Ang D, Bihorac A, McKinley BA, et al. Persistent inflammation and immunosuppression: a common syndrome and new horizon for surgical intensive care. J Trauma Acute Care Surg (2012) 72(6):1491-501. doi:10.1097/TA.0b013e318256e000

2. Mira JC, Brakenridge SC, Moldawer LL, Moore FA. Persistent inflammation, immunosuppression and catabolism syndrome. Crit Care Clin (2017) 33(2):245-58. doi:10.1016/j.ccc.2016.12.001

3. Venet F, Monneret G. Advances in the understanding and treatment of sepsis-induced immunosuppression. Nat Rev Nephrol (2018) 14(2):121-37. doi:10.1038/nrneph.2017.165

4. Claridge JA, Leukhardt WH, Golob JF, McCoy AM, Malangoni MA. Moving beyond traditional measurement of mortality after injury: evaluation of risks for late death. J Am Coll Surg (2010) 210(5):788-94. doi:10.1016/j. jamcollsurg.2009.12.035

5. Davidson GH, Hamlat CA, Rivara FP, Koepsell TD, Jurkovich GJ, Arbabi S. Long-term survival of adult trauma patients. JAMA (2011) 305(10):1001-7. doi:10.1001/jama.2011.259

6. Eriksson M, Brattstrom O, Larsson E, Oldner A. Causes of excessive late death after trauma compared with a matched control cohort. Br J Surg (2016) 103(10):1282-9. doi:10.1002/bjs.10197

7. Levy MM, Dellinger RP, Townsend SR, Linde-Zwirble WT, Marshall JC, Bion J, et al. The surviving sepsis campaign: results of an international to identify appropriate biomarkers, surrogate outcomes, and putative research approaches. Randomized clinical trials, using biomarker-driven adaptive study design, are also more rapidly moving potential therapeutics into the clinical setting.

\section{AUTHOR CONTRIBUTIONS}

$\mathrm{HH}, \mathrm{TL}, \mathrm{RH}, \mathrm{SR}$, JS, and PE drafted the manuscript. $\mathrm{MH}, \mathrm{BW}$, EM, AB, SL, AM, SB, HT, HU, FM, LM, and PE provided critical revisions. All authors made substantial contributions to the conception and design of the work, approved the submitted version of the manuscript, and agree to be accountable for all aspects of the work.

\section{ACKNOWLEDGMENTS}

The authors thank all clinicians and support staff of the Sepsis and Critical Illness Research Center at UF Shands Health engaged in ongoing sepsis and inflammation research.

\section{FUNDING}

This work was supported by grants R01 GM040586 (LM) awarded by the National Institute of General Medical Sciences (NIGMS). PE was supported by P30 AG028740 from the National Institute on Aging and by the NIH NIGMS grant R01 GM113945. AM was supported by NIH NIGMS grant R01 GM105893. AB was supported by the NIH NIGMS grant R01 GM110240. SL and LM were supported by the NIH NIGMS grant R01 GM097531. SB was supported by NIH NIA grant R03 AG056444. TL, RH, JS, and EM were supported by a training grant in burn and trauma research (T32 GM008431) from the NIGMS. SR was supported in part by a clinical research training fellowship awarded by the Surgical Infection Society Foundation. PE, AM, FM, SB, AB, and LM were supported by P50 GM111152 (NIGMS).

guideline-based performance improvement program targeting severe sepsis. Crit Care Med (2010) 38(2):367-74. doi:10.1097/CCM.0b013e3181cb0cdc

8. Mira JC, Gentile LF, Mathias BJ, Efron PA, Brakenridge SC, Mohr AM, et al. Sepsis pathophysiology, chronic critical illness, and persistent inflammation-immunosuppression and catabolism syndrome. Crit Care Med (2017) 45(2):253-62. doi:10.1097/CCM.0000000000002074

9. Stortz JA, Murphy TJ, Raymond SL, Mira JC, Ungaro R, Dirain ML, et al. Evidence for persistent immune suppression in patients WHO develop chronic critical illness after sepsis. Shock (2017) 49(3):249-58. doi:10.1097/ shk.0000000000000981

10. Mathias B, Delmas AL, Ozrazgat-Baslanti T, Vanzant EL, Szpila BE, Mohr AM, et al. Human myeloid-derived suppressor cells are associated with chronic immune suppression after severe sepsis/septic shock. Ann Surg (2017) 265(4):827-34. doi:10.1097/SLA.0000000000001783

11. Uhel F, Azzaoui I, Gregoire M, Pangault C, Dulong J, Tadie JM, et al. Early expansion of circulating granulocytic myeloid-derived suppressor cells predicts development of nosocomial infections in patients with sepsis. Am J Respir Crit Care Med (2017) 196(3):315-27. doi:10.1164/rccm.201606$1143 \mathrm{OC}$

12. Nacionales DC, Gentile LF, Vanzant E, Lopez MC, Cuenca A, Cuenca AG, et al. Aged mice are unable to mount an effective myeloid response to sepsis. J Immunol (2014) 192(2):612-22. doi:10.4049/jimmunol.1302109

13. Nacionales DC, Szpila B, Ungaro R, Lopez MC, Zhang J, Gentile LF, et al. A detailed characterization of the dysfunctional immunity and abnormal 
myelopoiesis induced by severe shock and trauma in the aged. J Immunol (2015) 195(5):2396-407. doi:10.4049/jimmunol.1500984

14. Hotchkiss RS, Moldawer LL, Opal SM, Reinhart K, Turnbull IR, Vincent JL. Sepsis and septic shock. Nat Rev Dis Primers (2016) 2:16045. doi:10.1038/nrdp.2016.45

15. Kawai $\mathrm{T}$, Akira $\mathrm{S}$. The role of pattern-recognition receptors in innate immunity: update on Toll-like receptors. Nat Immunol (2010) 11(5):373-84. doi:10.1038/ni.1863

16. Poltorak A, He X, Smirnova I, Liu MY, Van Huffel C, Du X, et al. Defective LPS signaling in $\mathrm{C} 3 \mathrm{H} / \mathrm{HeJ}$ and $\mathrm{C} 57 \mathrm{BL} / 10 \mathrm{ScCr}$ mice: mutations in TLR4 gene. Science (1998) 282(5396):2085-8. doi:10.1126/science.282.5396.2085

17. Stewart CR, Stuart LM, Wilkinson K, van Gils JM, Deng J, Halle A, et al. CD36 ligands promote sterile inflammation through assembly of a toll-like receptor 4 and 6 heterodimer. Nat Immunol (2010) 11(2):155-61. doi:10.1038/ni.1836

18. Sato M, Sano H, Iwaki D, Kudo K, Konishi M, Takahashi H, et al. Direct binding of Toll-like receptor 2 to zymosan, and zymosan-induced NF-kappa $\mathrm{B}$ activation and TNF-alpha secretion are down-regulated by lung collectin surfactant protein A. J Immunol (2003) 171(1):417-25. doi:10.4049/ jimmunol.171.1.417

19. Hayashi F, Smith KD, Ozinsky A, Hawn TR, Yi EC, Goodlett DR, et al. The innate immune response to bacterial flagellin is mediated by toll-like receptor 5. Nature (2001) 410(6832):1099-103. doi:10.1038/35074106

20. Akira $S$, Uematsu $S$, Takeuchi O. Pathogen recognition and innate immunity. Cell (2006) 124(4):783-801. doi:10.1016/j.cell.2006.02.015

21. Kawai T, Akira S. Toll-like receptors and their crosstalk with other innate receptors in infection and immunity. Immunity (2011) 34(5):637-50. doi:10.1016/j.immuni.2011.05.006

22. Alexopoulou L, Holt AC, Medzhitov R, Flavell RA. Recognition of doublestranded RNA and activation of NF-kappaB by toll-like receptor 3. Nature (2001) 413(6857):732-8. doi:10.1038/35099560

23. Hemmi H, Takeuchi O, Kawai T, Kaisho T, Sato S, Sanjo H, et al. A tolllike receptor recognizes bacterial DNA. Nature (2000) 408(6813):740-5. doi:10.1038/35047123

24. Tartey S, Takeuchi O. Pathogen recognition and toll-like receptor targeted therapeutics in innate immune cells. Int Rev Immunol (2017) 36(2):57-73. doi:10.1080/08830185.2016.1261318

25. Kingeter LM, Lin X. C-type lectin receptor-induced NF-[kgr]B activation in innate immune and inflammatory responses. Cell Mol Immunol (2012) 9(2):105-12. doi:10.1038/cmi.2011.58

26. Yamasaki S, Ishikawa E, Sakuma M, Hara H, Ogata K, Saito T. Mincle is an ITAM-coupled activating receptor that senses damaged cells. Nat Immunol (2008) 9(10):1179-88. doi:10.1038/ni.1651

27. Sabbah A, Chang TH, Harnack R, Frohlich V, Tominaga K, Dube PH, et al. Activation of innate immune antiviral responses by NOD2. Nat Immunol (2009) 10(10):1073-80. doi:10.1038/ni.1782

28. Coulombe F, Fiola S, Akira S, Cormier Y, Gosselin J. Muramyl dipeptide induces NOD2-dependent Ly6C(high) monocyte recruitment to the lungs and protects against influenza virus infection. PLoS One (2012) 7(5):e36734. doi:10.1371/journal.pone.0036734

29. Skeldon A, Saleh M. The inflammasomes: molecular effectors of host resistance against bacterial, viral, parasitic, and fungal infections. Front Microbiol (2011) 2:15. doi:10.3389/fmicb.2011.00015

30. Loo YM, Fornek J, Crochet N, Bajwa G, Perwitasari O, Martinez-Sobrido L, et al. Distinct RIG-I and MDA5 signaling by RNA viruses in innate immunity. J Virol (2008) 82(1):335-45. doi:10.1128/jvi.01080-07

31. Bruns AM, Pollpeter D, Hadizadeh N, Myong S, Marko JF, Horvath CM. ATP hydrolysis enhances RNA recognition and antiviral signal transduction by the innate immune sensor, laboratory of genetics and physiology 2 (LGP2). J Biol Chem (2013) 288(2):938-46. doi:10.1074/jbc.M112.424416

32. Bruns AM, Leser GP, Lamb RA, Horvath CM. The innate immune sensor LGP2 activates antiviral signaling by regulating MDA5-RNA interaction and filament assembly. Mol Cell (2014) 55(5):771-81. doi:10.1016/j.molcel.2014.07.003

33. Byun K, Yoo Y, Son M, Lee J, Jeong GB, Park YM, et al. Advanced glycation end-products produced systemically and by macrophages: a common contributor to inflammation and degenerative diseases. Pharmacol (2017) 177:44-55. doi:10.1016/j.pharmthera.2017.02.030

34. Sims GP, Rowe DC, Rietdijk ST, Herbst R, Coyle AJ. HMGB1 and RAGE in inflammation and cancer. Annu Rev Immunol (2010) 28:367-88. doi:10.1146/ annurev.immunol.021908.132603
35. Hofmann MA, Drury S, Fu C, Qu W, Taguchi A, Lu Y, et al. RAGE mediates a novel proinflammatory axis: a central cell surface receptor for S100/calgranulin polypeptides. Cell (1999) 97(7):889-901. doi:10.1016/ S0092-8674(00)80801-6

36. Peng J, Yuan Q, Lin B, Panneerselvam P, Wang X, Luan XL, et al. SARM inhibits both TRIF- and MyD88-mediated AP-1 activation. Eur J Immunol (2010) 40(6):1738-47. doi:10.1002/eji.200940034

37. Kawai T, Akira S. TLR signaling. Cell Death Differ (2006) 13(5):816-25. doi:10.1038/sj.cdd. 4401850

38. Takeuchi O, Akira S. Pattern recognition receptors and inflammation. Cell (2010) 140(6):805-20. doi:10.1016/j.cell.2010.01.022

39. Rivera A, Siracusa MC, Yap GS, Gause WC. Innate cell communication kick-starts pathogen-specific immunity. Nat Immunol (2016) 17(4):356-63. doi:10.1038/ni.3375

40. Kazzaz NM, Sule G, Knight JS. Intercellular interactions as regulators of NETosis. Front Immunol (2016) 7:453. doi:10.3389/fimmu. 2016.00453

41. Efron P, Moldawer LL. Sepsis and the dendritic cell. Shock (2003) 20(5): 386-401. doi:10.1097/01.SHK.0000092698.10326.6f

42. Mantegazza AR, Magalhaes JG, Amigorena S, Marks MS. Presentation of phagocytosed antigens by MHC class I and II. Traffic (2013) 14(2):135-52. doi:10.1111/tra.12026

43. Smyth MJ, Cretney E, Kelly JM, Westwood JA, Street SE, Yagita H, et al. Activation of NK cell cytotoxicity. Mol Immunol (2005) 42(4):501-10. doi:10.1016/j.molimm.2004.07.034

44. Delano MJ, Ward PA. The immune system's role in sepsis progression, resolution, and long-term outcome. Immunol Rev (2016) 274(1):330-53. doi:10.1111/imr.12499

45. Eberl G, Colonna M, Di Santo JP, McKenzie AN. Innate lymphoid cells. Innate lymphoid cells: a new paradigm in immunology. Science (2015) 348(6237):aaa6566. doi:10.1126/science.aaa6566

46. Opal SM. Phylogenetic and functional relationships between coagulation and the innate immune response. Crit Care Med (2000) 28(9 Suppl):S77-80. doi:10.1097/00003246-200009001-00017

47. Levi M, van der Poll T. Inflammation and coagulation. Crit Care Med (2010) 38(2 Suppl):S26-34. doi:10.1097/CCM.0b013e3181c98d21

48. Osterud B, Bjorklid E. Sources of tissue factor. Semin Thromb Hemost (2006) 32(1):11-23. doi:10.1055/s-2006-933336

49. Fuchs TA, Brill A, Duerschmied D, Schatzberg D, Monestier M, Myers DD Jr, et al. Extracellular DNA traps promote thrombosis. Proc Natl Acad Sci U S A (2010) 107(36):15880-5. doi:10.1073/pnas.1005743107

50. Yeaman MR. Platelets: at the nexus of antimicrobial defence. Nat Rev Microbiol (2014) 12(6):426-37. doi:10.1038/nrmicro3269

51. Ali RA, Wuescher LM, Dona KR, Worth RG. Platelets mediate host defense against Staphylococcus aureus through direct bactericidal activity and by enhancing macrophage activities. J Immunol (2017) 198(1):344-51. doi:10.4049/jimmunol.1601178

52. Gaertner F, Ahmad Z, Rosenberger G, Fan S, Nicolai L, Busch B, et al. Migrating platelets are mechano-scavengers that collect and bundle bacteria. Cell (2017) 171(6):1368.e-82.e. doi:10.1016/j.cell.2017.11.001

53. Foley JH. Examining coagulation-complement crosstalk: complement activation and thrombosis. Thromb Res (2016) 141(Suppl 2):S50-4. doi:10.1016/ s0049-3848(16)30365-6

54. Stark RJ, Aghakasiri N, Rumbaut RE. Platelet-derived toll-like receptor 4 (TLR-4) is sufficient to promote microvascular thrombosis in endotoxemia. PLoS One (2012) 7(7):e41254. doi:10.1371/journal.pone.0041254

55. Semeraro F, Ammollo CT, Morrissey JH, Dale GL, Friese P, Esmon NL, et al. Extracellular histones promote thrombin generation through plateletdependent mechanisms: involvement of platelet TLR2 and TLR4. Blood (2011) 118(7):1952-61. doi:10.1182/blood-2011-03-343061

56. Ghebrehiwet B. The complement system: an evolution in progress [version 1; referees: 2 approved]. F1000Res (2016) 5:2840. doi:10.12688/ f1000research.10065.1

57. Dunkelberger JR, Song WC. Complement and its role in innate and adaptive immune responses. Cell Res (2010) 20(1):34-50. doi:10.1038/cr. 2009.139

58. Degn SE, Thiel S. Humoral pattern recognition and the complement system. Scand J Immunol (2013) 78(2):181-93. doi:10.1111/sji.12070 
59. Riedemann NC, Guo RF, Sarma VJ, Laudes IJ, Huber-Lang M, Warner RL, et al. Expression and function of the C5a receptor in rat alveolar epithelial cells. J Immunol (2002) 168(4):1919-25. doi:10.4049/jimmunol.168.4.1919

60. Guo RF, Riedemann NC, Laudes IJ, Sarma VJ, Kunkel RG, Dilley KA, et al. Altered neutrophil trafficking during sepsis. J Immunol (2002) 169(1):307-14. doi:10.4049/jimmunol.169.1.307

61. Laudes IJ, Chu JC, Sikranth S, Huber-Lang M, Guo RF, Riedemann N, et al. Anti-c5a ameliorates coagulation/fibrinolytic protein changes in a rat model of sepsis. Am J Pathol (2002) 160(5):1867-75. doi:10.1016/ s0002-9440(10)61133-9

62. Lajoie S, Lewkowich IP, Suzuki Y, Clark JR, Sproles AA, Dienger K, et al. Complement-mediated regulation of the IL-17A axis is a central genetic determinant of the severity of experimental allergic asthma. Nat Immunol (2010) 11(10):928-35. doi:10.1038/ni.1926

63. Strainic MG, Shevach EM, An F, Lin F, Medof ME. Absence of signaling into CD4(+) cells via C3aR and C5aR enables autoinductive TGF-betal signaling and induction of Foxp3(+) regulatory T cells. Nat Immunol (2013) 14(2):162-71. doi:10.1038/ni.2499

64. Vieyra M, Leisman S, Raedler H, Kwan WH, Yang M, Strainic MG, et al. Complement regulates CD4 T-cell help to CD8 T cells required for murine allograft rejection. Am J Pathol (2011) 179(2):766-74. doi:10.1016/j.ajpath. 2011.04.038

65. Taylor RP, Ferguson PJ, Martin EN, Cooke J, Greene KL, Grinspun K, et al. Immune complexes bound to the primate erythrocyte complement receptor (CR1) via anti-CR1 mAbs are cleared simultaneously with loss of CR1 in a concerted reaction in a rhesus monkey model. Clin Immunol Immunopathol (1997) 82(1):49-59. doi:10.1006/clin.1996.4286

66. Molina H, Holers VM, Li B, Fung Y, Mariathasan S, Goellner J, et al. Markedly impaired humoral immune response in mice deficient in complement receptors 1 and 2. Proc Natl Acad Sci U S A (1996) 93(8):3357-61. doi:10.1073/ pnas.93.8.3357

67. Vogt L, Schmitz N, Kurrer MO, Bauer M, Hinton HI, Behnke S, et al. VSIG4, a B7 family-related protein, is a negative regulator of $\mathrm{T}$ cell activation. J Clin Invest (2006) 116(10):2817-26. doi:10.1172/jci25673

68. Jane-wit D, Surovtseva YV, Qin L, Li G, Liu R, Clark P, et al. Complement membrane attack complexes activate noncanonical NF-kappaB by forming an $\mathrm{Akt}^{+} \mathrm{NIK}^{+}$signalosome on Rab5 ${ }^{+}$endosomes. Proc Natl Acad Sci U S A (2015) 112(31):9686-91. doi:10.1073/pnas.1503535112

69. Sadik CD, Kim ND, Luster AD. Neutrophils cascading their way to inflammation. Trends Immunol (2011) 32(10):452-60. doi:10.1016/j.it.2011.06.008

70. Shi C, Pamer EG. Monocyte recruitment during infection and inflammation. Nat Rev Immunol (2011) 11(11):762-74. doi:10.1038/nri3070

71. Suratt BT, Petty JM, Young SK, Malcolm KC, Lieber JG, Nick JA, et al. Role of the CXCR4/SDF-1 chemokine axis in circulating neutrophil homeostasis. Blood (2004) 104(2):565-71. doi:10.1182/blood-2003-10-3638

72. Eash KJ, Greenbaum AM, Gopalan PK, Link DC. CXCR2 and CXCR4 antagonistically regulate neutrophil trafficking from murine bone marrow. J Clin Invest (2010) 120(7):2423-31. doi:10.1172/jci41649

73. Delano MJ, Kelly-Scumpia KM, Thayer TC, Winfield RD, Scumpia PO, Cuenca AG, et al. Neutrophil mobilization from the bone marrow during polymicrobial sepsis is dependent on CXCL12 signaling. J Immunol (2011) 187(2):911-8. doi:10.4049/jimmunol.1100588

74. Namikawa R, Muench MO, Roncarolo MG. Regulatory roles of the ligand for Flk2/Flt3 tyrosine kinase receptor on human hematopoiesis. Stem cells (1996) 14(4):388-95. doi:10.1002/stem.140388

75. Scumpia PO, Kelly-Scumpia KM, Delano MJ, Weinstein JS, Cuenca AG, Al-Quran S, et al. Cutting edge: bacterial infection induces hematopoietic stem and progenitor cell expansion in the absence of TLR signaling. J Immunol (2010) 184(5):2247-51. doi:10.4049/jimmunol.0903652

76. Claessens YE, Fontenay M, Pene F, Chiche JD, Guesnu M, Hababou C, et al. Erythropoiesis abnormalities contribute to early-onset anemia in patients with septic shock. Am J Respir Crit Care Med (2006) 174(1):51-7. doi:10.1164/rccm.200504-561OC

77. Ueda Y, Kondo M, Kelsoe G. Inflammation and the reciprocal production of granulocytes and lymphocytes in bone marrow. JExp Med (2005) 201(11):1771-80. doi:10.1084/jem.20041419

78. Chandra R, Villanueva E, Feketova E, Machiedo GW, Hasko G, Deitch EA, et al. Endotoxemia down-regulates bone marrow lymphopoiesis but stimulates myelopoiesis: the effect of G6PD deficiency. J Leukoc Biol (2008) 83(6):1541-50. doi:10.1189/jlb.1207838

79. Delano MJ, Scumpia PO, Weinstein JS, Coco D, Nagaraj S, Kelly-Scumpia KM, et al. MyD88-dependent expansion of an immature GR-1(+)CD11b(+) population induces T cell suppression and Th2 polarization in sepsis. J Exp Med (2007) 204(6):1463-74. doi:10.1084/jem.20062602

80. Hotchkiss RS, Tinsley KW, Swanson PE, Schmieg RE Jr, Hui JJ, Chang KC, et al. Sepsis-induced apoptosis causes progressive profound depletion of $\mathrm{B}$ and $\mathrm{CD}^{+} \mathrm{T}$ lymphocytes in humans. J Immunol (2001) 166(11):6952-63. doi:10.4049/jimmunol.166.11.6952

81. Alamo IG, Kannan KB, Bible LE, Loftus TJ, Ramos H, Efron PA, et al. Daily propranolol administration reduces persistent injury-associated anemia after severe trauma and chronic stress. J Trauma Acute Care Surg (2017) 82(4):714-21. doi:10.1097/ta.0000000000001374

82. Shorr AF, Jackson WL. Transfusion practice and nosocomial infection: assessing the evidence. Curr Opin Crit Care (2005) 11(5):468-72. doi:10.1097/ 01.ccx.0000176689.18433.f4

83. Youssef LA, Spitalnik SL. Transfusion-related immunomodulation: a reappraisal. Curr Opin Hematol (2017) 24(6):551-7. doi:10.1097/moh.0000000000000376

84. Youn JI, Nagaraj S, Collazo M, Gabrilovich DI. Subsets of myeloid-derived suppressor cells in tumor-bearing mice. J Immunol (2008) 181(8):5791-802. doi:10.4049/jimmunol.181.8.5791

85. Dietlin TA, Hofman FM, Lund BT, Gilmore W, Stohlman SA, van der Veen RC. Mycobacteria-induced $\mathrm{Gr}-1^{+}$subsets from distinct myeloid lineages have opposite effects on T cell expansion. JLeukoc Biol (2007) 81(5):1205-12. doi:10.1189/jlb.1006640

86. Gabrilovich DI, Velders MP, Sotomayor EM, Kast WM. Mechanism of immune dysfunction in cancer mediated by immature $\mathrm{Gr}-1^{+}$myeloid cells. J Immunol (2001) 166(9):5398-406. doi:10.4049/jimmunol.166.9.5398

87. Cuenca AG, Delano MJ, Kelly-Scumpia KM, Moreno C, Scumpia PO, Laface DM, et al. A paradoxical role for myeloid-derived suppressor cells in sepsis and trauma. Mol Med (2011) 17(3-4):281-92. doi:10.2119/ molmed.2010.00178

88. Hatziioannou A, Alissafi T, Verginis P. Myeloid-derived suppressor cells and T regulatory cells in tumors: unraveling the dark side of the force. J Leukoc Biol (2017) 102(2):407-21. doi:10.1189/jlb.5VMR1116-493R

89. Kamran N, Kadiyala P, Saxena M, Candolfi M, Li Y, Moreno-Ayala MA, et al. Immunosuppressive myeloid cells' blockade in the glioma microenvironment enhances the efficacy of immune-stimulatory gene therapy. Mol Ther (2017) 25(1):232-48. doi:10.1016/j.ymthe.2016.10.003

90. Chesney JA, Mitchell RA, Yaddanapudi K. Myeloid-derived suppressor cells-a new therapeutic target to overcome resistance to cancer immunotherapy. J Leukoc Biol (2017) 102(3):727-40. doi:10.1189/jlb.5VMR1116-458RRR

91. Noman MZ, Desantis G, Janji B, Hasmim M, Karray S, Dessen P, et al. PD-L1 is a novel direct target of HIF-lalpha, and its blockade under hypoxia enhanced MDSC-mediated T cell activation. J Exp Med (2014) 211(5):781-90. doi:10.1084/jem.20131916

92. Liu CY, Wang YM, Wang CL, Feng PH, Ko HW, Liu YH, et al. Population alterations of L-arginase- and inducible nitric oxide synthase-expressed

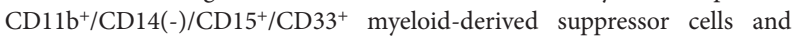
$\mathrm{CD}^{+} \mathrm{T}$ lymphocytes in patients with advanced-stage non-small cell lung cancer. J Cancer Res Clin Oncol (2010) 136(1):35-45. doi:10.1007/s00432009-0634-0

93. Otsuki N, Kamimura Y, Hashiguchi M, Azuma M. Expression and function of the B and T lymphocyte attenuator (BTLA/CD272) on human T cells. Biochem Biophys Res Commun (2006) 344(4):1121-7. doi:10.1016/j.bbrc. 2006.03.242

94. Heine A, Held SAE, Schulte-Schrepping J, Wolff JFA, Klee K, Ulas T, et al. Generation and functional characterization of MDSC-like cells. Oncoimmunology (2017)6(4):e1295203.doi:10.1080/2162402x.2017.1295203

95. Cuenca AG, Cuenca AL, Winfield RD, Joiner DN, Gentile L, Delano MJ, et al. Novel role for tumor-induced expansion of myeloid-derived cells in cancer cachexia. J Immunol (2014) 192(12):6111-9. doi:10.4049/jimmunol.1302895

96. Lim JJ, Grinstein S, Roth Z. Diversity and versatility of phagocytosis: roles in innate immunity, tissue remodeling, and homeostasis. Front Cell Infect Microbiol (2017) 7:191. doi:10.3389/fcimb.2017.00191

97. Green DR, Oguin TH, Martinez J. The clearance of dying cells: table for two. Cell Death Differ (2016) 23(6):915-26. doi:10.1038/cdd.2015.172 
98. Mallat M, Marin-Teva JL, Cheret C. Phagocytosis in the developing CNS: more than clearing the corpses. Curr Opin Neurobiol (2005) 15(1):101-7. doi:10.1016/j.conb.2005.01.006

99. Wynn TA, Vannella KM. Macrophages in tissue repair, regeneration, and fibrosis. Immunity (2016) 44(3):450-62. doi:10.1016/j.immuni.2016.02.015

100. Rabinovitch M. Professional and non-professional phagocytes: an introduction. Trends Cell Biol (1995) 5(3):85-7. doi:10.1016/S0962-8924(00) 88955-2

101. Nishimura K, Shindo S, Movila A, Kayal R, Abdullah A, Savitri IJ, et al. TRAP-positive osteoclast precursors mediate ROS/NO-dependent bactericidal activity via TLR4. Free Radic Biol Med (2016) 97:330-41. doi:10.1016/j. freeradbiomed.2016.06.021

102. Watanabe K, Misu T, Ohde S, Edamatsu H. Characteristics of eosinophils migrating around fungal hyphae in nasal discharge. Ann Otol Rhinol Laryngol (2004) 113(3 Pt 1):200-4. doi:10.1177/000348940411300305

103. Sprangers S, Behrendt N, Engelholm L, Cao Y, Everts V. Phagocytosis of collagen fibrils by fibroblasts in vivo is independent of the uPARAP/Endo180 receptor. J Cell Biochem (2017) 118(6):1590-5. doi:10.1002/jcb.25821

104. Tian B, Al-Moujahed A, Bouzika P, Hu Y, Notomi S, Tsoka P, et al. Atorvastatin promotes phagocytosis and attenuates pro-inflammatory response in human retinal pigment epithelial cells. Sci Rep (2017) 7(1):2329. doi:10.1038/ s41598-017-02407-7

105. Flannagan RS, Harrison RE, Yip CM, Jaqaman K, Grinstein S. Dynamic macrophage "probing" is required for the efficient capture of phagocytic targets. J Cell Biol (2010) 191(6):1205-18. doi:10.1083/jcb.201007056

106. Suvorova ES, Gripentrog JM, Miettinen HM. Different endocytosis pathways of the C5a receptor and the N-formyl peptide receptor. Traffic (2005) 6(2):100-15. doi:10.1111/j.1600-0854.2004.00256.x

107. Rosales C, Uribe-Querol E. Phagocytosis: a fundamental process in immunity. Biomed Res Int (2017) 2017:9042851. doi:10.1155/2017/9042851

108. Pauwels AM, Trost M, Beyaert R, Hoffmann E. Patterns, receptors, and signals: regulation of phagosome maturation. Trends Immunol (2017) 38(6):407-22. doi:10.1016/j.it.2017.03.006

109. Chow A, Toomre D, Garrett W, Mellman I. Dendritic cell maturation triggers retrograde $\mathrm{MHC}$ class II transport from lysosomes to the plasma membrane. Nature (2002) 418(6901):988-94. doi:10.1038/nature01006

110. Joffre OP, Segura E, Savina A, Amigorena S. Cross-presentation by dendritic cells. Nat Rev Immunol (2012) 12(8):557-69. doi:10.1038/nri3254

111. Garrett WS, Chen LM, Kroschewski R, Ebersold M, Turley S, Trombetta S, et al. Developmental control of endocytosis in dendritic cells by Cdc42. Cell (2000) 102(3):325-34. doi:10.1016/S0092-8674(00)00038-6

112. Guermonprez P, Valladeau J, Zitvogel L, Thery C, Amigorena S. Antigen presentation and $\mathrm{T}$ cell stimulation by dendritic cells. Annu Rev Immunol (2002) 20:621-67. doi:10.1146/annurev.immunol.20.100301.064828

113. Scumpia PO, McAuliffe PF, O’Malley KA, Ungaro R, Uchida T, Matsumoto T, et al. CD $11 \mathrm{c}^{+}$dendritic cells are required for survival in murine polymicrobial sepsis. J Immunol (2005) 175(5):3282-6. doi:10.4049/jimmunol.175.5.3282

114. Efron PA, Martins A, Minnich D, Tinsley K, Ungaro R, Bahjat FR, et al. Characterization of the systemic loss of dendritic cells in murine lymph nodes during polymicrobial sepsis. JImmunol (2004) 173(5):3035-43. doi:10.4049/jimmunol.173.5.3035

115. Fattahi F, Ward PA. Understanding immunosuppression after sepsis. Immunity (2017) 47(1):3-5. doi:10.1016/j.immuni.2017.07.007

116. Yan J, Li S, Li S. The role of the liver in sepsis. Int Rev Immunol (2014) 33(6):498-510. doi:10.3109/08830185.2014.889129

117. Bilzer M, Roggel F, Gerbes AL. Role of Kupffer cells in host defense and liverdisease. Liver Int (2006) 26(10):1175-86. doi:10.1111/j.1478-3231.2006. 01342.x

118. Lee WY, Moriarty TJ, Wong CH, Zhou H, Strieter RM, van Rooijen N, et al. An intravascular immune response to Borrelia burgdorferi involves Kupffer cells and iNKT cells. Nat Immunol (2010) 11(4):295-302. doi:10.1038/ni.1855

119. Gregory SH, Sagnimeni AJ, Wing EJ. Bacteria in the bloodstream are trapped in the liver and killed by immigrating neutrophils. J Immunol (1996) 157(6):2514-20.

120. Huang LR, Wohlleber D, Reisinger F, Jenne CN, Cheng RL, Abdullah Z, et al. Intrahepatic myeloid-cell aggregates enable local proliferation of CD8(+) $\mathrm{T}$ cells and successful immunotherapy against chronic viral liver infection. Nat Immunol (2013) 14(6):574-83. doi:10.1038/ni.2573
121. Shi J, Gilbert GE, Kokubo Y, Ohashi T. Role of the liver in regulating numbers of circulating neutrophils. Blood (2001) 98(4):1226-30. doi:10.1182/blood. V98.4.1226

122. Grozovsky R, Hoffmeister KM, Falet H. Novel clearance mechanisms of platelets. Curr Opin Hematol (2010) 17(6):585-9. doi:10.1097/ MOH.0b013e32833e7561

123. Fadok VA, Bratton DL, Konowal A, Freed PW, Westcott JY, Henson PM. Macrophages that have ingested apoptotic cells in vitro inhibit proinflammatory cytokine production through autocrine/paracrine mechanisms involving TGF-beta, PGE2, and PAF. J Clin Invest (1998) 101(4):890-8. doi: $10.1172 /$ jci1112

124. Fuchs Y, Steller H. Programmed cell death in animal development and disease. Cell (2011) 147(4):742-58. doi:10.1016/j.cell.2011.10.033

125. Taylor RC, Cullen SP, Martin SJ. Apoptosis: controlled demolition at the cellular level. Nat Rev Mol Cell Biol (2008) 9(3):231-41. doi:10.1038/nrm2312

126. Hotchkiss RS, Osmon SB, Chang KC, Wagner TH, Coopersmith CM, Karl IE. Accelerated lymphocyte death in sepsis occurs by both the death receptor and mitochondrial pathways. J Immunol (2005) 174(8):5110-8. doi:10.4049/ jimmunol.174.8.5110

127. Strasser A, Jost PJ, Nagata S. The many roles of FAS receptor signaling in the immune system. Immunity (2009) 30(2):180-92. doi:10.1016/j. immuni.2009.01.001

128. Lavrik IN, Krammer PH. Regulation of CD95/Fas signaling at the DISC. Cell Death Differ (2012) 19(1):36-41. doi:10.1038/cdd.2011.155

129. Dickens LS, Boyd RS, Jukes-Jones R, Hughes MA, Robinson GL, Fairall L, et al. A death effector domain chain DISC model reveals a crucial role for caspase- 8 chain assembly in mediating apoptotic cell death. Mol Cell (2012) 47(2):291-305. doi:10.1016/j.molcel.2012.05.004

130. Xiong S, Mu T, Wang G, Jiang X. Mitochondria-mediated apoptosis in mammals. Protein Cell (2014) 5(10):737-49. doi:10.1007/s13238-014-0089-1

131. Galvin JP, Spaeny-Dekking LH, Wang B, Seth P, Hack CE, Froelich CJ. Apoptosis induced by granzyme B-glycosaminoglycan complexes: implications for granule-mediated apoptosis in vivo. JImmunol (1999) 162(9):5345-50.

132. Huynh ML, Fadok VA, Henson PM. Phosphatidylserine-dependent ingestion of apoptotic cells promotes TGF-betal secretion and the resolution of inflammation. J Clin Invest (2002) 109(1):41-50. doi:10.1172/jci11638

133. Voll RE, Herrmann M, Roth EA, Stach C, Kalden JR, Girkontaite I. Immunosuppressive effects of apoptotic cells. Nature (1997) 390(6658): 350-1. doi:10.1038/37022

134. Kushwah R, Wu J, Oliver JR, Jiang G, Zhang J, Siminovitch KA, et al. Uptake of apoptotic DC converts immature DC into tolerogenic DC that induce differentiation of Foxp $3^{+}$Treg. Eur J Immunol (2010) 40(4):1022-35. doi:10.1002/eji.200939782

135. Boomer JS, To K, Chang KC, Takasu O, Osborne DF, Walton AH, et al. Immunosuppression in patients who die of sepsis and multiple organ failure. JAMA (2011) 306(23):2594-605. doi:10.1001/jama.2011.1829

136. Hotchkiss RS, Swanson PE, Freeman BD, Tinsley KW, Cobb JP, Matuschak GM, et al. Apoptotic cell death in patients with sepsis, shock, and multiple organ dysfunction. Crit Care Med (1999) 27(7):1230-51. doi:10.1097/00003246-199907000-00002

137. Hotchkiss RS, Tinsley KW, Swanson PE, Grayson MH, Osborne DF, Wagner TH, et al. Depletion of dendritic cells, but not macrophages, in patients with sepsis. J Immunol (2002) 168(5):2493-500. doi:10.4049/jimmunol.168.5.2493

138. Chung KP, Chang HT, Lo SC, Chang LY, Lin SY, Cheng A, et al. Severe lymphopenia is associated with elevated plasma interleukin-15 levels and increased mortality during severe sepsis. Shock (2015) 43(6):569-75. doi:10.1097/ shk.0000000000000347

139. Drewry AM, Samra N, Skrupky LP, Fuller BM, Compton SM, Hotchkiss RS. Persistent lymphopenia after diagnosis of sepsis predicts mortality. Shock (2014) 42(5):383-91. doi:10.1097/shk.0000000000000234

140. Kaczmarek A, Vandenabeele P, Krysko DV. Necroptosis: the release of damage-associated molecular patterns and its physiological relevance. Immunity (2013) 38(2):209-23. doi:10.1016/j.immuni.2013.02.003

141. Upton JW, Kaiser WJ, Mocarski ES. DAI/ZBP1/DLM-1 complexes with RIP3 to mediate virus-induced programmed necrosis that is targeted by murine cytomegalovirus vIRA. Cell Host Microbe (2012) 11(3):290-7. doi:10.1016/j. chom.2012.01.016 
142. Kaiser WJ, Upton JW, Mocarski ES. Viral modulation of programmed necrosis. Curr Opin Virol (2013) 3(3):296-306. doi:10.1016/j.coviro.2013.05.019

143. Kayagaki N, Stowe IB, Lee BL, O’Rourke K, Anderson K, Warming S, et al. Caspase-11 cleaves gasdermin D for non-canonical inflammasome signalling. Nature (2015) 526(7575):666-71. doi:10.1038/nature15541

144. Jorgensen I, Zhang Y, Krantz BA, Miao EA. Pyroptosis triggers pore-induced intracellular traps (PITs) that capture bacteria and lead to their clearance by efferocytosis. JExp Med (2016) 213(10):2113-28. doi:10.1084/jem. 20151613

145. Festjens N, Vanden Berghe T, Vandenabeele P. Necrosis, a well-orchestrated form of cell demise: signalling cascades, important mediators and concomitant immune response. Biochim Biophys Acta (2006) 1757(9-10):1371-87. doi:10.1016/j.bbabio.2006.06.014

146. Lockshin RA, Zakeri Z. Cell death in health and disease. JCell Mol Med (2007) 11(6):1214-24. doi:10.1111/j.1582-4934.2007.00150.x

147. He S, Wang L, Miao L, Wang T, Du F, Zhao L, et al. Receptor interacting protein kinase-3 determines cellular necrotic response to TNF-alpha. Cell (2009) 137(6):1100-11. doi:10.1016/j.cell.2009.05.021

148. Cookson BT, Brennan MA. Pro-inflammatory programmed cell death. Trends Microbiol (2001) 9(3):113-4. doi:10.1016/S0966-842X(00)01936-3

149. Singer M,Deutschman CS,SeymourCW,Shankar-HariM, AnnaneD, BauerM, et al. The third international consensus definitions for sepsis and septic shock (sepsis-3). JAMA (2016) 315(8):801-10. doi:10.1001/jama.2016.0287

150. Flick MJ, Du X, Witte DP, Jirouskova M, Soloviev DA, Busuttil SJ, et al. Leukocyte engagement of fibrin(ogen) via the integrin receptor alphaMbeta2/Mac-1 is critical for host inflammatory response in vivo. J Clin Invest (2004) 113(11):1596-606. doi:10.1172/jci20741

151. Luo D, Szaba FM, Kummer LW, Plow EF, Mackman N, Gailani D, et al. Protective roles for fibrin, tissue factor, plasminogen activator inhibitor-1, and thrombin activatable fibrinolysis inhibitor, but not factor XI, during defense against the Gram-negative bacterium Yersinia enterocolitica. J Immunol (2011) 187(4):1866-76. doi:10.4049/jimmunol.1101094

152. Opal SM, Esmon CT. Bench-to-bedside review: functional relationships between coagulation and the innate immune response and their respective roles in the pathogenesis of sepsis. Crit Care (2003) 7(1):23-38. doi:10.1186/ cc2219

153. Gando S, Levi M, Toh CH. Disseminated intravascular coagulation. Nat Rev Dis Primers (2016) 2:16037. doi:10.1038/nrdp.2016.37

154. Ogura H, Gando S, Saitoh D, Takeyama N, Kushimoto S, Fujishima S, et al. Epidemiology of severe sepsis in Japanese intensive care units: a prospective multicenter study. J Infect Chemother (2014) 20(3):157-62. doi:10.1016/j. jiac.2013.07.006

155. Levi M, van der Poll T. Coagulation and sepsis. Thromb Res (2017) 149:38-44. doi:10.1016/j.thromres.2016.11.007

156. Bengtson A, Heideman M. Anaphylatoxin formation in sepsis. Arch Surg (1988) 123(5):645-9. doi:10.1001/archsurg.1988.01400290131023

157. Nakae H, Endo S, Inada K, Yoshida M. Chronological changes in the complement system in sepsis. Surg Today (1996) 26(4):225-9. doi:10.1007/ BF00311579

158. Ward PA. The dark side of C5a in sepsis. Nat Rev Immunol (2004) 4(2): 133-42. doi:10.1038/nri1269

159. Yan C, Gao H. New insights for $\mathrm{C} 5 \mathrm{a}$ and $\mathrm{C} 5 \mathrm{a}$ receptors in sepsis. Front Immunol (2012) 3:368. doi:10.3389/fimmu.2012.00368

160. Niederbichler AD, Hoesel LM, Westfall MV, Gao H, Ipaktchi KR, Sun L, et al. An essential role for complement C5a in the pathogenesis of septic cardiac dysfunction. J Exp Med (2006) 203(1):53-61. doi:10.1084/jem.20051207

161. Guo RF, Riedemann NC, Bernacki KD, Sarma VJ, Laudes IJ, Reuben JS, et al. Neutrophil C5a receptor and the outcome in a rat model of sepsis. FASEB J (2003) 17(13):1889-91. doi:10.1096/ff.03-0009fje

162. Rittirsch D, Flierl MA, Nadeau BA, Day DE, Huber-Lang M, Mackay CR, et al. Functional roles for C5a receptors in sepsis. Nat Med (2008) 14(5):551-7. doi: $10.1038 / \mathrm{nm} 1753$

163. Chen NJ, Mirtsos C, Suh D, Lu YC, Lin WJ, McKerlie C, et al. C5L2 is critical for the biological activities of the anaphylatoxins C5a and C3a. Nature (2007) 446(7132):203-7. doi:10.1038/nature05559

164. Wright HL, Thomas HB, Moots RJ, Edwards SW. RNA-seq reveals activation of both common and cytokine-specific pathways following neutrophil priming. PLoS One (2013) 8(3):e58598. doi:10.1371/journal.pone. 0058598
165. DeLeo FR, Renee J, McCormick S, Nakamura M, Apicella M, Weiss JP, et al. Neutrophils exposed to bacterial lipopolysaccharide upregulate NADPH oxidase assembly. J Clin Invest (1998) 101(2):455-63. doi:10.1172/jci949

166. Wrann CD, Winter SW, Barkhausen T, Hildebrand F, Krettek C, Riedemann NC. Distinct involvement of p38-, ERK1/2 and PKC signaling pathways in C5amediated priming of oxidative burst in phagocytic cells. Cell Immunol (2007) 245(2):63-9. doi:10.1016/j.cellimm.2007.04.001

167. Babior BM. Phagocytes and oxidative stress. Am J Med (2000) 109(1):33-44. doi:10.1016/S0002-9343(00)00481-2

168. Gupta AK, Joshi MB, Philippova M, Erne P, Hasler P, Hahn S, et al. Activated endothelial cells induce neutrophil extracellular traps and are susceptible to NETosis-mediated cell death. FEBS Lett (2010) 584(14):3193-7. doi:10.1016/j.febslet.2010.06.006

169. Delabranche X, Stiel L, Severac F, Galoisy AC, Mauvieux L, Zobairi F, et al. Evidence of netosis in septic shock-induced disseminated intravascular coagulation. Shock (2017) 47(3):313-7. doi:10.1097/shk.0000000000000719

170. Czaikoski PG, Mota JM, Nascimento DC, Sonego F, Castanheira FV, Melo PH et al. Neutrophil extracellular traps induce organ damage during experimental and clinical sepsis. PLoS One (2016) 11(2):e0148142. doi:10.1371/journal. pone. 0148142

171. Johansson PI, Windelov NA, Rasmussen LS, Sorensen AM, Ostrowski SR. Blood levels of histone-complexed DNA fragments are associated with coagulopathy, inflammation and endothelial damage early after trauma. J Emerg Trauma Shock (2013) 6(3):171-5. doi:10.4103/0974-2700.115327

172. Xu J, Zhang X, Pelayo R, Monestier M, Ammollo CT, Semeraro F, et al. Extracellular histones are major mediators of death in sepsis. Nat Med (2009) 15(11):1318-21. doi:10.1038/nm.2053

173. Meirow Y, Kanterman J, Baniyash M. Paving the road to tumor development and spreading: myeloid-derived suppressor cells are ruling the fate. Front Immunol (2015) 6:523. doi:10.3389/fimmu.2015.00523

174. Crook KR, Liu P. Role of myeloid-derived suppressor cells in autoimmune disease. World J Immunol (2014) 4(1):26-33. doi:10.5411/wji.v4.i1.26

175. Ezernitchi AV, Vaknin I, Cohen-Daniel L, Levy O, Manaster E, Halabi A, et al. TCR zeta down-regulation under chronic inflammation is mediated by myeloid suppressor cells differentially distributed between various lymphatic organs. J Immunol (2006) 177(7):4763-72. doi:10.4049/jimmunol.177.7.4763

176. Bunt SK, Yang L, Sinha P, Clements VK, Leips J, Ostrand-Rosenberg S. Reduced inflammation in the tumor microenvironment delays the accumulation of myeloid-derived suppressor cells and limits tumor progression. Cancer Res (2007) 67(20):10019-26. doi:10.1158/0008-5472.can-07-2354

177. Joo YD, Lee SM, Lee SW, Lee WS, Lee SM, Park JK, et al. Granulocyte colony-stimulating factor-induced immature myeloid cells inhibit acute graft-versus-host disease lethality through an indoleamine dioxygenaseindependent mechanism. Immunology (2009) 128(1 Suppl):e632-40. doi:10.1111/j.1365-2567.2009.03048.x

178. Serafini P, Carbley R, Noonan KA, Tan G, Bronte V, Borrello I. High-dose granulocyte-macrophage colony-stimulating factor-producing vaccines impair the immune response through the recruitment of myeloid suppressor cells. Cancer Res (2004) 64(17):6337-43. doi:10.1158/0008-5472.can-04-0757

179. Gabrilovich D, Ishida T, Oyama T, Ran S, Kravtsov V, Nadaf S, et al. Vascular endothelial growth factor inhibits the development of dendritic cells and dramatically affects the differentiation of multiple hematopoietic lineages in vivo. Blood (1998) 92(11):4150-66.

180. Zhu X, Pribis JP, Rodriguez PC, Morris SM Jr, Vodovotz Y, Billiar TR, et al. The central role of arginine catabolism in T-cell dysfunction and increased susceptibility to infection after physical injury. Ann Surg (2014) 259(1):171-8. doi:10.1097/SLA.0b013e31828611f8

181. Darcy CJ, Minigo G, Piera KA, Davis JS, McNeil YR, Chen Y, et al. Neutrophils with myeloid derived suppressor function deplete arginine and constrain $\mathrm{T}$ cell function in septic shock patients. Crit Care (2014) 18(4):R163. doi:10.1186/cc14003

182. Vaknin I, Blinder L, Wang L, Gazit R, Shapira E, Genina O, et al. A common pathway mediated through Toll-like receptors leads to T- and natural killer-cell immunosuppression. Blood (2008) 111(3):1437-47. doi:10.1182/ blood-2007-07-100404

183. Sander LE, Sackett SD, Dierssen U, Beraza N, Linke RP, Muller M, et al. Hepatic acute-phase proteins control innate immune responses during infection by promoting myeloid-derived suppressor cell function. J Exp Med (2010) 207(7):1453-64. doi:10.1084/jem.20091474 
184. Janols H, Bergenfelz C, Allaoui R, Larsson AM, Ryden L, Bjornsson S, et al. A high frequency of MDSCs in sepsis patients, with the granulocytic subtype dominating in Gram-positive cases. JLeukoc Biol (2014) 96(5):685-93. doi:10.1189/jlb.5HI0214-074R

185. Hotchkiss RS, Moldawer LL. Parallels between cancer and infectious disease. N Engl J Med (2014) 371(4):380-3. doi:10.1056/NEJMcibr1404664

186. Mira JC, Cuschieri J, Ozrazgat-Baslanti T, Wang Z, Ghita GL, Loftus TJ, et al. The epidemiology of chronic critical illness after severe traumatic injury at two-level one trauma centers. Crit Care Med (2017) 45(12):1989-96. doi:10.1097/ccm.0000000000002697

187. Loftus TJ, Mira JC, Ozrazgat-Baslanti T, Ghita GL, Wang Z, Stortz JA, et al. Sepsis and critical illness research center investigators: protocols and standard operating procedures for a prospective cohort study of sepsis in critically ill surgical patients. BMJ Open (2017) 7(7):e015136. doi:10.1136/ bmjopen-2016-015136

188. Rosenthal MD, Moore FA. Persistent inflammatory, immunosuppressed, catabolic syndrome (PICS): a new phenotype of multiple organ failure. J Adv Nut Hum Metab (2015) 1(1):e784. doi:10.14800/janhm.784

189. Yang N, Li B, Ye B, Ke L, Chen F, Lu G, et al. The long-term quality of life in patients with persistent inflammation-immunosuppression and catabolism syndrome after severe acute pancreatitis: a retrospective cohort study. J Crit Care (2017) 42:101-6. doi:10.1016/j.jcrc.2017.07.013

190. Needham DM, Davidson J, Cohen H, Hopkins RO, Weinert C, Wunsch H, et al. Improving long-term outcomes after discharge from intensive care unit: report from a stakeholders' conference. Crit Care Med (2012) 40(2):502-9. doi:10.1097/CCM.0b013e318232da75

191. Pugh AM, Auteri NJ, Goetzman HS, Caldwell CC, Nomellini V. A murine model of persistent inflammation, immune suppression, and catabolism syndrome. Int J Mol Sci (2017) 18(8):E1741. doi:10.3390/ijms18081741

192. Stortz JA, Raymond SL, Mira JC, Moldawer LL, Mohr AM, Efron PA. Murine models of sepsis and trauma: can we bridge the gap? ILAR J (2017) 58(1):90-105. doi:10.1093/ilar/ilx007

193. Efron PA, Mohr AM, Moore FA, Moldawer LL. The future of murine sepsis and trauma research models. J Leukoc Biol (2015) 98(6):945-52. doi:10.1189/ jlb.5MR0315-127R

194. Brummel NE, Balas MC, Morandi A, Ferrante LE, Gill TM, Ely EW. Understanding and reducing disability in older adults following critical illness. Crit Care Med (2015) 43(6):1265-75. doi:10.1097/CCM. 0000000000000924

195. Baldwin MR. Measuring and predicting long-term outcomes in older survivors of critical illness. Minerva Anestesiol (2015) 81(6):650-61.

196. Hazeldine J, Lord JM, Hampson P. Immunesenescence and inflammaging: a contributory factor in the poor outcome of the geriatric trauma patient. Ageing Res Rev (2015) 24(Pt B):349-57. doi:10.1016/j.arr.2015.10.003

197. Olivieri F, Rippo MR, Monsurro V, Salvioli S, Capri M, Procopio AD, et al. MicroRNAs linking inflamm-aging, cellular senescence and cancer. Ageing Res Rev (2013) 12(4):1056-68. doi:10.1016/j.arr.2013.05.001

198. Kumar G, Kumar N, Taneja A, Kaleekal T, Tarima S, McGinley E, et al. Nationwide trends of severe sepsis in the 21st century (2000-2007). Chest (2011) 140(5):1223-31. doi:10.1378/chest.11-0352

199. Martin GS, Mannino DM, Eaton S, Moss M. The epidemiology of sepsis in the United States from 1979 through 2000. N Engl J Med (2003) 348(16):1546-54. doi:10.1056/NEJMoa022139

200. Kang SC, Matsutani T, Choudhry MA, Schwacha MG, Rue LW, Bland KI, et al. Are the immune responses different in middle-aged and young mice following bone fracture, tissue trauma and hemorrhage? Cytokine (2004) 26(5):223-30. doi:10.1016/j.cyto.2004.03.005

201. Moore FA, Sauaia A, Moore EE, Haenel JB, Burch JM, Lezotte DC. Postinjury multiple organ failure: a bimodal phenomenon. J Trauma (1996) 40(4): 501-10; discussion 10-2. doi:10.1097/00005373-199604000-00001

202. Kozar RA, Arbabi S, Stein DM, Shackford SR, Barraco RD, Biffl WL, et al. Injury in the aged: geriatric trauma care at the crossroads. J Trauma Acute Care Surg (2015) 78(6):1197-209. doi:10.1097/TA.000000000 0000656

203. Vanzant EL, Hilton RE, Lopez CM, Zhang J, Ungaro RF, Gentile LF, et al. Advanced age is associated with worsened outcomes and a unique genomic response in severely injured patients with hemorrhagic shock. Crit Care (2015) 19:77. doi:10.1186/s13054-015-0788-x
204. Martin GS, Mannino DM, Moss M. The effect of age on the development and outcome of adult sepsis. Crit Care Med (2006) 34(1):15-21. doi:10.1097/01. CCM.0000194535.82812.BA

205. Weng NP. Aging of the immune system: how much can the adaptive immune system adapt? Immunity (2006) 24(5):495-9. doi:10.1016/j.immuni. 2006.05.001

206. Solana R, Pawelec G, Tarazona R. Aging and innate immunity. Immunity (2006) 24(5):491-4. doi:10.1016/j.immuni.2006.05.003

207. Suzuki K, Inoue S, Kametani Y, Komori Y, Chiba S, Sato T, et al. Reduced immunocompetent B cells and increased secondary infection in elderly patients with severe sepsis. Shock (2016) 46(3):270-8. doi:10.1097/SHK. 0000000000000619

208. Nomellini V, Kaplan LJ, Sims CA, Caldwell CC. Chronic critical illness and persistent inflammation: what can we learn from the elderly, injured, septic, and malnourished? Shock (2018) 49(1):4-14. doi:10.1097/shk. 0000000000000939

209. Delano MJ, Thayer T, Gabrilovich S, Kelly-Scumpia KM, Winfield RD, Scumpia PO, et al. Sepsis induces early alterations in innate immunity that impact mortality to secondary infection. J Immunol (2011) 186(1):195-202. doi:10.4049/jimmunol.1002104

210. Dykstra B, Olthof S, Schreuder J, Ritsema M, de Haan G. Clonal analysis reveals multiple functional defects of aged murine hematopoietic stem cells. J Exp Med (2011) 208(13):2691-703. doi:10.1084/jem.20111490

211. Guerrettaz LM, Johnson SA, Cambier JC. Acquired hematopoietic stem cell defects determine B-cell repertoire changes associated with aging. Proc Natl Acad Sci U S A (2008) 105(33):11898-902. doi:10.1073/pnas.0805498105

212. Williams MD, Braun LA, Cooper LM, Johnston J, Weiss RV, Qualy RL, et al. Hospitalized cancer patients with severe sepsis: analysis of incidence, mortality, and associated costs of care. Crit Care (2004) 8(5):R291-8. doi:10.1186/ cc2893

213. White MC, Holman DM, Boehm JE, Peipins LA, Grossman M, Henley SJ. Age and cancer risk: a potentially modifiable relationship. Am J Prev Med (2014) 46(3 Suppl 1):S7-15. doi:10.1016/j.amepre.2013.10.029

214. Palmer S, Albergante L, Blackburn CC, Newman TJ. Thymic involution and rising disease incidence with age. Proc Natl Acad Sci U S A (2018) 115(8):1883-8. doi:10.1073/pnas.1714478115

215. Goldszmid RS, Dzutsev A, Trinchieri G. Host immune response to infection and cancer: unexpected commonalities. Cell Host Microbe (2014) 15(3):295-305. doi:10.1016/j.chom.2014.02.003

216. Pietras EM, Warr MR, Passegue E. Cell cycle regulation in hematopoietic stem cells. J Cell Biol (2011) 195(5):709-20. doi:10.1083/jcb.201102131

217. Boettcher S, Ziegler P, Schmid MA, Takizawa H, van Rooijen N, Kopf M, et al. Cutting edge: LPS-induced emergency myelopoiesis depends on TLR4-expressing nonhematopoietic cells. J Immunol (2012) 188(12):5824-8. doi:10.4049/jimmunol.1103253

218. Boiko JR, Borghesi L. Hematopoiesis sculpted by pathogens: toll-like receptors and inflammatory mediators directly activate stem cells. Cytokine (2012) 57(1):1-8. doi:10.1016/j.cyto.2011.10.005

219. Baldridge MT, King KY, Goodell MA. Inflammatory signals regulate hematopoietic stem cells. Trends Immunol (2011) 32(2):57-65. doi:10.1016/j. it.2010.12.003

220. Nelson S, Belknap SM, Carlson RW, Dale D, DeBoisblanc B, Farkas S, et al. A randomized controlled trial of filgrastim as an adjunct to antibiotics for treatment of hospitalized patients with community-acquired pneumonia. CAP study group. J Infect Dis (1998) 178(4):1075-80. doi:10.1086/515694

221. Root RK, Lodato RF, Patrick W, Cade JF, Fotheringham N, Milwee S, et al. Multicenter, double-blind, placebo-controlled study of the use of filgrastim in patients hospitalized with pneumonia and severe sepsis. Crit Care Med (2003) 31(2):367-73. doi:10.1097/01.ccm.0000048629.32625.5d

222. Paine R III, Standiford TJ, Dechert RE, Moss M, Martin GS, Rosenberg AL, et al. A randomized trial of recombinant human granulocyte-macrophage colony stimulating factor for patients with acute lung injury. Crit Care Med (2012) 40(1):90-7. doi:10.1097/CCM.0b013e31822d7bf0

223. Meisel C, Schefold JC, Pschowski R, Baumann T, Hetzger K, Gregor J, et al. Granulocyte-macrophage colony-stimulating factor to reverse sepsis-associated immunosuppression: a double-blind, randomized, placebo-controlled multicenter trial. Am J Respir Crit Care Med (2009) 180(7):640-8. doi:10.1164/rccm.200903-0363OC 
224. Bo L, Wang F, Zhu J, Li J, Deng X. Granulocyte-colony stimulating factor (G-CSF) and granulocyte-macrophage colony stimulating factor (GM-CSF) for sepsis: a meta-analysis. Crit Care (2011) 15(1):R58. doi:10.1186/cc10031

225. Hutchins NA, Unsinger J, Hotchkiss RS, Ayala A. The new normal: immunomodulatory agents against sepsis immune suppression. Trends $\mathrm{Mol} \mathrm{Med}$ (2014) 20(4):224-33. doi:10.1016/j.molmed.2014.01.002

226. Unsinger J, Burnham CA, McDonough J, Morre M, Prakash PS, Caldwell CC, et al. Interleukin-7 ameliorates immune dysfunction and improves survival in a 2-hit model of fungal sepsis. J Infect Dis (2012) 206(4):606-16. doi:10.1093/infdis/jis383

227. Kasten KR, Prakash PS, Unsinger J, Goetzman HS, England LG, Cave CM, et al. Interleukin-7 (IL-7) treatment accelerates neutrophil recruitment through gamma delta T-cell IL-17 production in a murine model of sepsis. Infect Immun (2010) 78(11):4714-22. doi:10.1128/iai.00456-10

228. Inoue S, Unsinger J, Davis CG, Muenzer JT, Ferguson TA, Chang K, et al. IL-15 prevents apoptosis, reverses innate and adaptive immune dysfunction, and improves survival in sepsis. JImmunol (2010) 184(3):1401-9. doi:10.4049/jimmunol.0902307

229. Nalos M, Santner-Nanan B, Parnell G, Tang B, McLean AS, Nanan R. Immune effects of interferon gamma in persistent staphylococcal sepsis. Am J Respir Crit Care Med (2012) 185(1):110-2. doi:10.1164/ajrccm.185.1.110

230. Chang KC, Burnham CA, Compton SM, Rasche DP, Mazuski RJ, McDonough JS, et al. Blockade of the negative co-stimulatory molecules PD-1 and CTLA-4 improves survival in primary and secondary fungal sepsis. Crit Care (2013) 17(3):R85. doi:10.1186/cc12711

231. Huang X, Venet F, Wang YL, Lepape A, Yuan Z, Chen Y, et al. PD-1 expression by macrophages plays a pathologic role in altering microbial clearance and the innate inflammatory response to sepsis. Proc Natl Acad Sci U S A (2009) 106(15):6303-8. doi:10.1073/pnas.0809422106

232. Inoue $\mathrm{S}$, Bo L, Bian J, Unsinger J, Chang K, Hotchkiss RS. Dose-dependent effect of anti-CTLA-4 on survival in sepsis. Shock (2011) 36(1):38-44. doi:10.1097/SHK.0b013e3182168cce

233. Yang X, Jiang X, Chen G, Xiao Y, Geng S, Kang C, et al. T cell Ig mucin-3 promotes homeostasis of sepsis by negatively regulating the TLR response. J Immunol (2013) 190(5):2068-79. doi:10.4049/jimmunol.1202661

234. Zhao Z, Jiang X, Kang C, Xiao Y, Hou C, Yu J, et al. Blockade of the T cell immunoglobulin and mucin domain protein 3 pathway exacerbates sepsisinduced immune deviation and immunosuppression. Clin Exp Immunol (2014) 178(2):279-91. doi:10.1111/cei.12401

235. Workman CJ, Wang Y, El Kasmi KC, Pardoll DM, Murray PJ, Drake CG, et al. LAG-3 regulates plasmacytoid dendritic cell homeostasis. J Immunol (2009) 182(4):1885-91. doi:10.4049/jimmunol.0800185

236. Durham NM, Nirschl CJ, Jackson CM, Elias J, Kochel CM, Anders RA, et al. Lymphocyte activation gene 3 (LAG-3) modulates the ability of CD4 T-cells to be suppressed in vivo. PLoS One (2014) 9(11):e109080. doi:10.1371/ journal.pone.0109080

237. Wu J, Zhou L, Liu J, Ma G, Kou Q, He Z, et al. The efficacy of thymosin alpha 1 for severe sepsis (ETASS): a multicenter, single-blind, randomized and controlled trial. Critical care (2013) 17(1):R8. doi:10.1186/cc11932

238. Wischmeyer PE, San-Millan I. Winning the war against ICU-acquired weakness: new innovations in nutrition and exercise physiology. Crit Care (2015) 19(Suppl 3):S6. doi:10.1186/cc14724

239. Puthucheary ZA, Rawal J, McPhail M, Connolly B, Ratnayake G, Chan P, et al. Acute skeletal muscle wasting in critical illness. JAMA (2013) 310(15):1591-600. doi:10.1001/jama.2013.278481

240. Moore FA, Phillips SM, McClain CJ, Patel JJ, Martindale RG. Nutrition support for persistent inflammation, immunosuppression, and catabolism syndrome. Nutr Clin Pract (2017) 32(1_suppl):121s-7s. doi:10.1177/0884533616687502

241. Bozzetti F, Arends J, Lundholm K, Micklewright A, Zurcher G, Muscaritoli M. ESPEN guidelines on parenteral nutrition: non-surgical oncology. Clin Nut (2009) 28(4):445-54. doi:10.1016/j.clnu.2009.04.011

242. Wolfe RR, Miller SL, Miller KB. Optimal protein intake in the elderly. Clin Nut (2008) 27(5):675-84. doi:10.1016/j.clnu.2008.06.008

243. Morley JE, Argiles JM, Evans WJ, Bhasin S, Cella D, Deutz NE, et al. Nutritional recommendations for the management of sarcopenia. J Am Med Dir Assoc (2010) 11(6):391-6. doi:10.1016/j.jamda.2010.04.014

244. Herndon DN, Tompkins RG. Support of the metabolic response to burn injury. Lancet (2004) 363(9424):1895-902. doi:10.1016/s0140-6736(04)16360-5
245. Wu G, Bazer FW, Davis TA, Kim SW, Li P, Marc Rhoads J, et al. Arginine metabolism and nutrition in growth, health and disease. Amino Acids (2009) 37(1):153-68. doi:10.1007/s00726-008-0210-y

246. Zea AH, Rodriguez PC, Culotta KS, Hernandez CP, DeSalvo J, Ochoa JB, et al. L-Arginine modulates CD3zeta expression and $\mathrm{T}$ cell function in activated human T lymphocytes. Cell Immunol (2004) 232(1-2):21-31. doi:10.1016/j. cellimm.2005.01.004

247. Schlegel L, Coudray-Lucas C, Barbut F, Le Boucher J, Jardel A, Zarrabian S, et al. Bacterial dissemination and metabolic changes in rats induced by endotoxemia following intestinal $E$. coli overgrowth are reduced by ornithine alpha-ketoglutarate administration. J Nutr (2000) 130(12):2897-902. doi:10.1093/jn/130.12.2897

248. English KL, Mettler JA, Ellison JB, Mamerow MM, Arentson-Lantz E, Pattarini JM, et al. Leucine partially protects muscle mass and function during bed rest in middle-aged adults. Am J Clin Nutr (2016) 103(2):465-73. doi:10.3945/ajcn.115.112359

249. Cerra FB, Siegel JH, Coleman B, Border JR, McMenamy RR. Septic autocannibalism. A failure of exogenous nutritional support. Ann Surg (1980) 192(4):570-80. doi:10.1097/00000658-198010000-00015

250. Hernandez-Garcia AD, Columbus DA, Manjarin R, Nguyen HV, Suryawan A, Orellana RA, et al. Leucine supplementation stimulates protein synthesis and reduces degradation signal activation in muscle of newborn pigs during acute endotoxemia. Am J Physiol Endocrinol Metab (2016) 311(4):E791-801. doi:10.1152/ajpendo.00217.2016

251. Cynober L, de Bandt JP, Moinard C. Leucine and citrulline: two major regulators of protein turnover. World Rev Nutr Diet (2013) 105:97-105. doi:10.1159/000341278

252. Hrynyk M, Neufeld RJ. Insulin and wound healing. Burns (2014) 40(8): 1433-46. doi:10.1016/j.burns.2014.03.020

253. Herndon DN, Voigt CD, Capek KD, Wurzer P, Guillory A, Kline A, et al. Reversal of growth arrest with the combined administration of oxandrolone and propranolol in severely burned children. Ann Surg (2016) 264(3):421-8. doi:10.1097/sla.0000000000001844

254. Diaz EC, Herndon DN, Porter C, Sidossis LS, Suman OE, Borsheim E. Effects of pharmacological interventions on muscle protein synthesis and breakdown in recovery from burns. Burns (2015) 41(4):649-57. doi:10.1016/j. burns.2014.10.010

255. Kayambu G, Boots R, Paratz J. Physical therapy for the critically ill in the ICU: a systematic review and meta-analysis. Crit Care Med (2013) 41(6):1543-54. doi:10.1097/CCM.0b013e31827ca637

256. Cermak NM, Res PT, de Groot LC, Saris WH, van Loon LJ. Protein supplementation augments the adaptive response of skeletal muscle to resistance-type exercise training: a meta-analysis. Am J Clin Nutr (2012) 96(6):1454-64. doi:10.3945/ajcn.112.037556

257. Thaiss CA, Zmora N, Levy M, Elinav E. The microbiome and innate immunity. Nature (2016) 535(7610):65-74. doi:10.1038/nature18847

258. Khosravi A, Yanez A, Price JG, Chow A, Merad M, Goodridge HS, et al. Gut microbiota promote hematopoiesis to control bacterial infection. Cell Host Microbe (2014) 15(3):374-81. doi:10.1016/j.chom.2014.02.006

259. Zhang D, Chen G, Manwani D, Mortha A, Xu C, Faith JJ, et al. Neutrophil ageing is regulated by the microbiome. Nature (2015) 525(7570):528-32. doi:10.1038/nature15367

260. Shimizu K, Ogura H, Hamasaki T, Goto M, Tasaki O, Asahara T, et al. Altered gut flora are associated with septic complications and death in critically ill patients with systemic inflammatory response syndrome. Dig Dis Sci (2011) 56(4):1171-7. doi:10.1007/s10620-010-1418-8

261. Shimizu K, Ogura H, Asahara T, Nomoto K, Morotomi M, Nakahori Y, et al. Gastrointestinal dysmotility is associated with altered gut flora and septic mortality in patients with severe systemic inflammatory response syndrome: a preliminary study. Neurogastroenterol Motil (2011) 23(4):330-5,e157. doi:10.1111/j.1365-2982.2010.01653.x

262. Stecher B, Maier L, Hardt WD. 'Blooming' in the gut: how dysbiosis might contribute to pathogen evolution. Nat Rev Microbiol (2013) 11(4):277-84. doi:10.1038/nrmicro2989

263. Buffie CG, Bucci V, Stein RR, McKenney PT, Ling L, Gobourne A, et al. Precision microbiome reconstitution restores bile acid mediated resistance to Clostridium difficile. Nature (2015) 517(7533):205-8. doi:10.1038/ nature 13828 
264. Fan J, Li G, Wu L, Tao S, Wang W, Sheng Z, et al. Parenteral glutamine supplementation in combination with enteral nutrition improves intestinal immunity in septic rats. Nutrition (2015) 31(5):766-74. doi:10.1016/j. nut.2014.11.021

265. van Nood E, Vrieze A, Nieuwdorp M, Fuentes S, Zoetendal EG, de Vos WM, et al. Duodenal infusion of donor feces for recurrent Clostridium difficile. $N$ Engl JMed (2013) 368(5):407-15. doi:10.1056/NEJMoa 1205037

266. Zaborin A, Defazio JR, Kade M, Kaiser BL, Belogortseva N, Camp DG II, et al. Phosphate-containing polyethylene glycol polymers prevent lethal sepsis by multidrug-resistant pathogens. Antimicrob Agents Chemother (2014) 58(2):966-77. doi:10.1128/aac.02183-13

267. Christaki E, Giamarellos-Bourboulis EJ. The beginning of personalized medicine in sepsis: small steps to a bright future. Clin Genet (2014) 86(1):56-61. doi:10.1111/cge.12368

268. Wang L, Ko ER, Gilchrist JJ, Pittman KJ, Rautanen A, Pirinen M, et al. Human genetic and metabolite variation reveals that methylthioadenosine is a prognostic biomarker and an inflammatory regulator in sepsis. Sci Adv (2017) 3(3):e1602096. doi:10.1126/sciadv.1602096

269. Burnham KL, Davenport EE, Radhakrishnan J, Humburg P, Gordon AC, Hutton $\mathrm{P}$, et al. Shared and distinct aspects of the sepsis transcriptomic response to fecal peritonitis and pneumonia. Am J Respir Crit Care Med (2017) 196(3):328-39. doi:10.1164/rccm.201608-1685OC
270. Cuenca AG, Gentile LF, Lopez MC, Ungaro R, Liu H, Xiao W, et al. Development of a genomic metric that can be rapidly used to predict clinical outcome in severely injured trauma patients. Crit Care Med (2013) 41(5):1175-85. doi:10.1097/CCM.0b013e318277131c

271. LeCun Y, Bengio Y, Hinton G. Deep learning. Nature (2015) 521(7553): 436-44. doi:10.1038/nature14539

272. Tsoukalas A, Albertson T, Tagkopoulos I. From data to optimal decision making: a data-driven, probabilistic machine learning approach to decision support for patients with sepsis. JMIR Med Inform (2015) 3(1):e11. doi:10.2196/medinform.3445

Conflict of Interest Statement: The authors declare that the research was conducted in the absence of any commercial or financial relationships that could be construed as a potential conflict of interest.

Copyright (C) 2018 Horiguchi, Loftus, Hawkins, Raymond, Stortz, Hollen, Weiss, Miller Bihorac, Larson, Mohr, Brakenridge, Tsujimoto, Ueno, Moore, Moldawer, Efron and The Sepsis and Critical Illness Research Center Investigators. This is an open-access article distributed under the terms of the Creative Commons Attribution License (CC $B Y)$. The use, distribution or reproduction in other forums is permitted, provided the original author(s) and the copyright owner are credited and that the original publication in this journal is cited, in accordance with accepted academic practice. No use, distribution or reproduction is permitted which does not comply with these terms. 